\title{
Methane and nitrous oxide from ground-based FTIR at Addis Ababa: observations, error analysis, and comparison with satellite data
}

\author{
Temesgen Yirdaw Berhe ${ }^{1}$, Gizaw Mengistu Tsidu ${ }^{1,2}$, Thomas Blumenstock ${ }^{3}$, Frank Hase ${ }^{3}$, and Gabriele P. Stiller ${ }^{3}$ \\ ${ }^{1}$ Department of Physics, Addis Ababa University, P.O. Box 1176, Addis Ababa, Ethiopia \\ ${ }^{2}$ Department of Earth and Environmental Sciences, College of Science, Botswana International University of Science \\ and Technology (BIUST), Priv. Bag 16, Palapye, Botswana \\ ${ }^{3}$ Institute of Meteorology and Climate Research (IMK-ASF), Karlsruhe Institute of Technology (KIT), Karlsruhe, Germany
}

Correspondence: Temesgen Yirdaw Berhe (temiephys@gmail.com)

Received: 23 April 2019 - Discussion started: 28 May 2019

Revised: 4 May 2020 - Accepted: 18 June 2020 - Published: 30 July 2020

\begin{abstract}
A ground-based, high-spectral-resolution Fourier transform infrared (FTIR) spectrometer has been operational in Addis Ababa, Ethiopia (9.01 ${ }^{\circ} \mathrm{N}$ latitude, $38.76^{\circ} \mathrm{E}$ longitude; $2443 \mathrm{~m}$ altitude above sea level), since May 2009 to obtain information on column abundances and profiles of various constituents in the atmosphere. Vertical profile and column abundances of methane and nitrous oxide are derived from solar absorption measurements taken by FTIR for a period that covers May 2009 to March 2013 using the retrieval code PROFFIT (V9.5). A detailed error analysis of $\mathrm{CH}_{4}$ and $\mathrm{N}_{2} \mathrm{O}$ retrieval are performed. Averaging kernels of the target gases shows that the major contribution to the retrieved information comes from the measurement. Thus, average degrees of freedom for signals are found to be 2.1 and 3.4, from the retrieval of $\mathrm{CH}_{4}$ and $\mathrm{N}_{2} \mathrm{O}$ for the total observed FTIR spectra. Methane and nitrous oxide volume mixing ratio (VMR) profiles and column amounts retrieved from FTIR spectra are compared with data from the reduced spectral resolution Institute of Meteorology and Climate Research/Instituto de Astrofísica de Andalucía (IMK/IAA) MIPAS (Version V5R_CH4_224 and V5R_N2O_224), the Microwave Limb Sounder (MLS) (MLS v3.3 of $\mathrm{N}_{2} \mathrm{O}$ and $\mathrm{CH}_{4}$ derived from MLS v3.3 products of $\mathrm{CO}, \mathrm{N}_{2} \mathrm{O}$, and $\mathrm{H}_{2} \mathrm{O}$ ), and the Atmospheric Infrared Sounder (AIRS) sensors on board satellites. The averaged mean relative difference between FTIR methane and the three correlative instruments MIPAS, MLS, and AIRS are 4.2\%, 5.8\%, and $5.3 \%$ in the altitude ranges of 20 to $27 \mathrm{~km}$, respectively. However, the biases below $20 \mathrm{~km}$ are negative, which indicates the profile of
\end{abstract}

$\mathrm{CH}_{4}$ from FTIR is less than the profiles derived from correlative instruments by $-4.9 \%,-1.8 \%$, and $-2.8 \%$. The averaged positive bias between FTIR nitrous oxide and correlative instrument, MIPAS, in the altitude range of 20 to $27 \mathrm{~km}$ is $7.8 \%$, and a negative bias of $-4 \%$ at altitudes below $20 \mathrm{~km}$. An averaged positive bias of $9.3 \%$ in the altitude range of 17 to $27 \mathrm{~km}$ is obtained for FTIR $\mathrm{N}_{2} \mathrm{O}$ with MLS. In all the comparisons of $\mathrm{CH}_{4}$ from FTIR with data from MIPAS, MLS, and AIRS, sensors on board satellites indicate a negative bias below $20 \mathrm{~km}$ and a positive bias above $20 \mathrm{~km}$. The mean error between partial-column amounts of methane from MIPAS and the ground-based FTIR is $-5.5 \%$, with a standard deviation of $5 \%$ that shows very good agreement as exhibited by relative differences between vertical profiles. Thus, the retrieved $\mathrm{CH}_{4}$ and $\mathrm{N}_{2} \mathrm{O}$ VMR and column amounts from Addis Ababa, tropical site, is found to exhibit very good agreement with all coincident satellite observations. Therefore, the bias obtained from the comparison is comparable to the precision of FTIR measurement, which allows the use of data in further scientific studies as it represents a unique environment of tropical Africa, a region poorly investigated in the past.

\section{Introduction}

Methane $\left(\mathrm{CH}_{4}\right)$, nitrous oxide $\left(\mathrm{N}_{2} \mathrm{O}\right)$, and chlorofluorocarbons (CFCs) are tropospheric species, which are the main 
source gases for the chemical families $\mathrm{NO}_{x}, \mathrm{ClO}_{x}$, and $\mathrm{HO}_{x}$ (Jacobson, 2005). The reaction of $\mathrm{CH}_{4}$ with hydroxyl radicals reduces ozone in the troposphere, and it influences the lifetime or production of other atmospheric constituents such as stratospheric water vapor and $\mathrm{CO}_{2}$ (Michelsen et al., 2000; Boucher et al., 2009), whereas the lifetime of $\mathrm{N}_{2} \mathrm{O}$ is determined by its rate of UV photolysis or reaction with $\mathrm{O}\left({ }^{1} \mathrm{D}\right)$ (Collins et al., 2010).

Methane retrievals from near-infrared spectra recorded by the SCIAMACHY instrument on board ENVISAT suggested an unexpectedly large tropical $\mathrm{CH}_{4}$ emissions and the impact of water spectroscopy on methane retrievals, with the largest impacts in the tropics (Frankenberg et al., 2008b). The recent increasing impact of $\mathrm{CH}_{4}$ and $\mathrm{N}_{2} \mathrm{O}$ to global warming has also been assessed by the last AR4 IPCC report (IPCC, 2007; Sussmann et al., 2012). Nitrous oxide $\left(\mathrm{N}_{2} \mathrm{O}\right)$ becomes the dominant ozone-depleting substance emitted in the 21st century (Ravishankara et al., 2009). In 2007 and 2008, The Infrared Atmospheric Sounding Interferometer (IASI) on board METOP-A observed an increase in midtroposphere methane in the tropical region of $9.5 \pm 2.8$ and $6.3 \pm 1.7 \mathrm{ppbv} \mathrm{yr}^{-1}$, respectively (Crevoisier et al., 2013). Long-lived compounds ascend in the tropics, across the tropical tropopause, and are subsequently redistributed by the Brewer-Dobson circulation (Holton, 2004). According to the World Meteorological Organization (WMO), the 2010 report (WMO, 2010), $96 \%$ of the increase in radiative forcing is due to the five long-lived greenhouse gases: carbon dioxide, methane, nitrous oxide, CFC-12, and CFC-11. The sources and sinks of atmospheric methane $\left(\mathrm{CH}_{4}\right)$ and its budget in the tropics are not yet well quantified and have large uncertainties due to the scarcity of measurements (e.g., Meirink et al., 2008).

The tropics is the location where two important exchange processes in the atmosphere are taking place, the interhemispheric exchange and the entry of tropospheric air mass into the stratosphere (Petersen et al., 2010; Fueglistaler et al., 2009). Moreover, composition of a tropical atmosphere also plays a critical role in the stratospheric chemistry (Solomon, 1999; IPCC, 2007). Measurements and interpretation of atmospheric trace gas composition of the tropics is vital for a better understanding of the budgets, sources, and sinks of trace gases in the atmosphere and their effects on atmospheric chemistry, greenhouse effect, and climate changes globally. Emissions within the tropics contribute substantially to the global budgets of many important trace gases (IPCC, 2007; Frankenberg et al., 2008a).

The ground-based FTIR measurement at the Addis Ababa site was launched in 2009, in collaboration with Karlsruhe Institute of Technology, Germany, to measure concentrations of various trace gases in the lower and middle atmosphere over Addis Ababa. Thus, Addis Ababa FTIR measurements of atmospheric trace gases and their importance to understand various lower and middle atmospheric processes have been reported in a number of previous studies (Takele Ke- nea et al., 2013; Mengistu Tsidu et al., 2015; Schneider et al., 2015, 2016; Barthlott et al., 2017). $\mathrm{H}_{2} \mathrm{O}$ volume mixing ratio (VMR) profiles and integrated column amounts from ground-based FTIR measurements of the Addis Ababa site were also compared with the coincident satellite observations of the Tropospheric Emission Spectrometer (TES), Atmospheric Infrared Sounding (AIRS), and Modular Earth Submodel System (MESSy) model, and the result confirmed reasonably good agreement (Samuel, 2014). Laeng et al. (2015) found that the MIPAS $\mathrm{CH}_{4}$ profiles V5R_CH4_222 below 20 to $25 \mathrm{~km}$ is biased high by $+14 \%$. For a later and improved data version, namely V5R_CH4_224, Plieninger et al. (2016) found a positive bias between 0.1 and $0.2 \mathrm{ppmv}$. For the MIPAS $\mathrm{N}_{2} \mathrm{O}$ data version V5R_N2O_224, Plieninger et al. (2016) determined the bias to be between 0 and $+30 \mathrm{ppb}$.

In this study, previous work on the intercomparison of ozone (Takele Kenea et al., 2013) and water vapor (Samuel, 2014) are extended to source gases $\mathrm{CH}_{4}$ and $\mathrm{N}_{2} \mathrm{O}$ from ground-based FTIR. Intercomparisons of vertical profiles and column amounts retrieved from solar spectra observed by the Fourier transform spectrometer at the Addis Ababa site with data from MIPAS, MLS, and AIRS sensors on board satellites were made to assess the quality of the data derived from FTIR. The observed differences between ground-based FTIR and satellite observation of $\mathrm{CH}_{4}$ and $\mathrm{N}_{2} \mathrm{O}$ are analyzed using the statistical tools detailed in von Clarmann (2006). The measurement site and the FTIR spectrometer along with the retrieval approach will be introduced in Sect. 2, and the retrieved information content and spectral analysis will be discussed in Sect. 3. A short description of satellite measurement techniques followed by the detailed intercomparison with those products will be presented in Sects. 4 and 5, respectively. Finally, a summary and conclusions are given in Sect. 6.

\section{Measurement site and instrumentation}

\subsection{Measurement site}

The ground-based FTIR at Addis Ababa was established to acquire high-quality, long-term measurements of trace gases to understand chemical and dynamical processes in the atmosphere and to validate models and satellite measurements of atmospheric constituents. The geographic position of the observatory is $9.01^{\circ} \mathrm{N}, 38.76^{\circ} \mathrm{E}, 2443 \mathrm{~m}$ a.s.l., and its suitability has been confirmed from the measurements of tropical stratospheric ozone, precipitable water vapor, and isotopic composition of water vapor (Takele Kenea et al., 2013; Mengistu Tsidu et al., 2015; Schneider et al., 2015, 2016; Barthlott et al., 2017). Addis Ababa is a tropical high-altitude observing site and as such is important to the understanding of processes near the tropical tropopause. Physical process in the tropics, mainly around tropopause layer, has a vital role in climate change and the general circulation of the tropi- 
cal troposphere, which would control the transport of energy, water vapor, and trace gases in the climate system derived by the deep convection (Holton and Gettelman, 2001). Thus, the observed variation in the measurement of atmospheric trace gases would help us to understand the effects of tropical dynamics on the site. Besides, it fills a data gap due to the scarcity of ground-based measurements in tropics.

\subsection{The FTIR spectrometer and retrieval}

Fourier transform spectroscopy has been applied successfully to study trace gases in the atmosphere by examining atmospheric absorption lines in the infrared spectrum from solar radiation. Measurement of the sun's spectra at the Earth's surface provides information about atmospheric composition. This technique uses the sun as a light source in order to quantify molecular absorptions in the atmosphere and then retrieve trace gases abundance. The high-resolution FTIR spectrometer, Bruker IFS120M, upgraded with $125 \mathrm{M}$ electronics, from Bruker Optik GmbH, in Germany, was installed in May 2009 at the Addis Ababa site. This interferometer is equipped with indium-antimonide ( $\mathrm{InSb}$ ) detector, which allows coverage of the $1500-4400 \mathrm{~cm}^{-1}$ spectral interval. In this spectral range, a large number of species that reside in the atmosphere can be detected.

The measured spectra have been analyzed using an algorithm that simulates the spectra and Jacobians by the lineby-line radiative transfer model PRFFWD (PRoFit ForWarD model) to produce the synthesized spectra, and the vertical profiles of $\mathrm{CH}_{4}$ and $\mathrm{N}_{2} \mathrm{O}$ would be derived by applying a retrieval code PROFFIT (Ver95) (Hase et al., 2004). It has been developed based on semiempirical implementation of the optimal estimation method (Rodgers, 2000) to derive the VMR profiles and column amounts of multiple species. Hence, $\mathrm{CH}_{4}$ and $\mathrm{N}_{2} \mathrm{O}$ profiles from measured spectra in the microwindows that span a spectral range of $2400-2800 \mathrm{~cm}^{-1}$ have been discussed in this paper. A Tikhonov-Phillips regularization method on a logarithmic scale was used to derive the profiles. Retrieved state vector $\hat{\boldsymbol{x}}$ is related to a priori $\left(\boldsymbol{x}_{\mathrm{a}}\right)$ and true state vectors $(\boldsymbol{x})$ by the following mathematical expression:

$\hat{\boldsymbol{x}}=\boldsymbol{x}_{\mathrm{a}}+\hat{\mathbf{A}}\left(\boldsymbol{x}-\boldsymbol{x}_{\mathrm{a}}\right)+\varepsilon$,

where $\hat{\mathbf{A}}$ is averaging kernel matrix, and $\varepsilon$ is the measurement error. Moreover, the actual averaging kernel matrix depends on several parameters including the solar zenith angle, the spectral resolution and signal-to-noise ratio, the choice of retrieval spectral microwindows, and the a priori covariance matrix $\mathbf{S}_{\mathrm{a}}$. The elements of the averaging kernel for a given altitude gives the sensitivity of retrieved profiles at which the real profile is present, and its full width at half maximum is a measure of the vertical resolution of the retrieval at that altitude (Rodgers, 1990). Error estimation analysis is based on the analytical method suggested by Rodgers (2000) as fol- lows:

$\hat{\boldsymbol{x}}-\boldsymbol{x}=(\mathbf{A}-\mathbf{I})\left(\boldsymbol{x}-\boldsymbol{x}_{x}\right)+\mathbf{G K}_{b}\left(\boldsymbol{b}-\boldsymbol{b}_{a}\right)+\mathbf{G} \varepsilon$.

The averaging kernel matrix can be defined as $\mathbf{A}=\mathbf{G K}$; $\mathbf{I}$ is the identity matrix, and $\mathbf{G}$ is the gain matrix that represents the sensitivity of retrieved parameters to the measurement. $\mathbf{K}_{b}$ is the sensitivity matrix of the spectrum to the forward model parameters $\boldsymbol{b}$. Since we do not know the true state of the atmosphere, we can not specify the actual retrieval error; we can only make a statistical estimate of it, which is expressed in terms of a covariance matrix. The total error in the retrieved profile can be described as a combination of measurement error and forward model parameter error. It has been suggested by Rodgers (2000) to include smoothing error in the total error budget, but this concept has been revised by von Clarmann (2014).

\section{Information content and error analysis}

\subsection{Spectroscopic data and a priori profiles}

In our retrieval strategy, the profiles of $\mathrm{CH}_{4}$ and $\mathrm{N}_{2} \mathrm{O}$ were retrieved, while the profiles of interfering species (see Table 1) were scaled. A prior $x_{\mathrm{a}}$ profiles for methane and the interfering species above Addis Ababa were taken from 40-year averages (1980-2020) of the Whole Atmosphere Community Climate Model (WACCM; Garcia et al., 2007). Similarly, the a priori profile for nitrous oxide has also been constructed from monthly average data available from WACCM (e.g., Tilmes et al., 2007), whereas the grid to be used for the Addis Ababa site is found with the WACCM mixing ratio profile data at ftp://ftp.acom.ucar.edu/user/jamesw/IRWG/2013/ WACCM/V6/Addis_Ababa/ (last access: 21 July 2020), as recommended by the NDACC/IRWG (Network for the Detection of Atmospheric Composition Change/ Infrared Working Group). WACCM is a numerical model developed at the National Center for Atmospheric Research (NCAR). Daily profiles of pressure and temperature were taken from the National Centers for Environmental Prediction (NCEP) (http://www.cdc.noaa.gov/data/gridded/ data.ncep.reanalysis.html) (last access: 21 July 2020) reanalysis and are made available through the NASA Goddard Space Flight Center automailer. The spectroscopic parameters were taken from the HITRAN (high-resolution transmission molecular absorption) database, version 2008, for $\mathrm{N}_{2} \mathrm{O}$, and 2009 for $\mathrm{H}_{2} \mathrm{O}$ (Rothmann et al., 2009), and the updated HITRAN 2012 for $\mathrm{CO}, \mathrm{CH}_{4}$, and $\mathrm{NO}_{2}$ (Rothmann et al., 2013) were used during retrieval of $\mathrm{CH}_{4}$ and $\mathrm{N}_{2} \mathrm{O}$.

Both methane $\left(\mathrm{CH}_{4}\right)$ and nitrous oxide $\left(\mathrm{N}_{2} \mathrm{O}\right)$ are well mixed in the troposphere, and their VMR decreases with height and becomes negligible with no variation above $55 \mathrm{~km}$. The vertical variability in $\mathrm{N}_{2} \mathrm{O}$ and $\mathrm{CH}_{4}$ in the lower stratosphere is characterized by a somewhat higher vertical gradient as compared to the other layers. Both 
Table 1. Microwindows, interfering gases, and their DOFs listed in the table are used for the retrieval of VMR profiles and column amounts of $\mathrm{CH}_{4}$ and $\mathrm{N}_{2} \mathrm{O}$ from FTIR spectra recorded at Addis Ababa.

\begin{tabular}{lrlr}
\hline Gas & Microwindow $\left(\mathrm{cm}^{-1}\right)$ & Interfering species & DOFs \\
\hline $\mathrm{CH}_{4}$ & $(2599.8,2600.5)$ & $\mathrm{H}_{2} \mathrm{O}, \mathrm{CO}_{2}, \mathrm{NO}_{2}$ & $2.045 \pm 0.18$ \\
& $(2614.87,2615.4)$ & & \\
& $(2650.8,2651.29)$ & & \\
& $(2760.6,2761.23)$ & & \\
& $(2778.22,2778.55)$ & & \\
\hline $\mathrm{N}_{2} \mathrm{O}$ & $(2464.2,2465.57)$ & $\mathrm{H}_{2} \mathrm{O}, \mathrm{CO}_{2}, \mathrm{CH}_{4}$ & $3.38 \pm 0.15$ \\
& $(2486.55,2488.18)$ & & \\
& $(2491.86,2492.9)$ & & \\
& $(2522.95,2524.1)$ & & \\
\hline
\end{tabular}

profiles and columns of $\mathrm{CH}_{4}$ and $\mathrm{N}_{2} \mathrm{O}$ over Addis Ababa have been obtained by fitting five and four selected spectral regions for $\mathrm{CH}_{4}$ and $\mathrm{N}_{2} \mathrm{O}$, respectively. Here, spectral microwindows used for the retrieval are selected such that they contain absorption features of the target species along with a minimal number of interfering absorption lines; and they have been adopted from different sources (Senten et al., 2008; Sussmann et al., 2011; Meier et al., 2004). Microwindows, target, and interfering species used in this paper are summarized in Table 1. However, the microwindows are somewhat modified for the Addis Ababa FTIR site from the windows recommended by NDACC, as mentioned in a result of work done within the EU UFTIR projects (http://projects.amap.no/project/uftirtime-series-of-upper-free-troposphere-observations-from -a-european-ground-based-ftir-network/, last access: 21 July 2020). The choice of these microwindows over those recommended by NDACC is due to their improved performance as indicated in the Supplement. The main criterion for selection of these microwindows is high sensitivity to methane and low interference from other gases. Our tests have shown that these windows are still appropriate for the Addis Ababa site. Methane and nitrous oxide vertical profiles over Addis Ababa have been obtained by fitting five and four microwindows, respectively. The retrieved state vector contains volume mixing ratios of the target gas defined in 41 layers of the tropical atmospheric conditions.

PROFFIT includes various retrieval options such as scaling of a priori profile, the Tikhonov-Phillips method (Phillips, 1962; Tikhonov, 1963), or the optimal estimation method (Rodgers, 2000). In this study, an optimized retrieval strategy for Addis Ababa has been established for $\mathrm{CH}_{4}$ and $\mathrm{N}_{2} \mathrm{O}$ by applying it first to single spectra, as test cases, and later routinely to the full set of measurements. Partly, the strategy to optimally retrieve the total columns of $\mathrm{CH}_{4}$ and $\mathrm{N}_{2} \mathrm{O}$ is to search for a set of spectra microwindows. A constraint, initial guess, and a priori profile are chosen in such a way that all the structures visible in the retrieved distributions originate from the measurements and are not artifacts due to any constraints. At the Addis Ababa site, we did not use the a priori covariance matrix as an optimal estimation. However, the Tikhonov-type $\mathrm{L}_{1}$ regularization method (Sussmann et al., 2009) on a logarithmic scale is used during the retrieval of $\mathrm{CH}_{4}$ and $\mathrm{N}_{2} \mathrm{O}$. The retrieval is performed on a fine vertical grid from 2.45 to $85 \mathrm{~km}$ and is stabilized by a first-order Tikhonov constraint, $R=\alpha L^{T} L$, where $\alpha$ is the strength of the constraint, and $\mathrm{L}_{1}$ is the first-order derivative (Borsdorff et al., 2014), which smooths the solution without biasing it towards the a priori profile. The parameter determines the weight of regularization, and it is also important to choose it to be appropriate to the problem. One way to fix this parameter is the L-curve method (Hansen, 1992). The regularization strength $\alpha$, is determined by finding a tradeoff between the number of degrees of freedom (a measure of the amount of information in methane and nitrous oxide retrieval), which is given by the trace of the averaging kernel matrix and the noise-induced error (Rodgers, 2000). A regularization strength $\alpha$ of $2.5 \times 10^{4}$ was found optimum for $\mathrm{CH}_{4}$ retrieval.

The spectral fit and residual between measured and simulated spectra at five microwindows for $\mathrm{CH}_{4}$ are shown in Fig. 1 for spectra recorded on 26 February 2013. Four microwindows are used for $\mathrm{N}_{2} \mathrm{O}$ and depicted in Fig. 2 for spectra recorded on 31 December 2009. The last column of Table 1 provides typical values for the degrees of freedom for signal (DOFs), and it indicates the possible independent pieces of information for the target gases distribution. The magnitude of residuals found from spectral fits span a range from a maximum of $+0.25 \%$ to $-0.64 \%$ for $\mathrm{CH}_{4}$ and $+0.34 \%$ to $-0.34 \%$ for $\mathrm{N}_{2} \mathrm{O}$. Hence, the residuals indicate systematic errors in the spectroscopic line data used to derive the concentration of $\mathrm{CH}_{4}$ and $\mathrm{N}_{2} \mathrm{O}$. Therefore, the fits are good with an averaged root-mean-square residual of $0.12 \%$ for the microwindows selected in the retrieval of $\mathrm{CH}_{4}$.

The quality of FTIR measurements during time period of May 2009-February 2011 for ozone has been revealed by Takele Kenea et al. (2013), whereas the measurements quality for $\mathrm{CH}_{4}$ and $\mathrm{N}_{2} \mathrm{O}$ has also been assessed through the sen- 
(a)
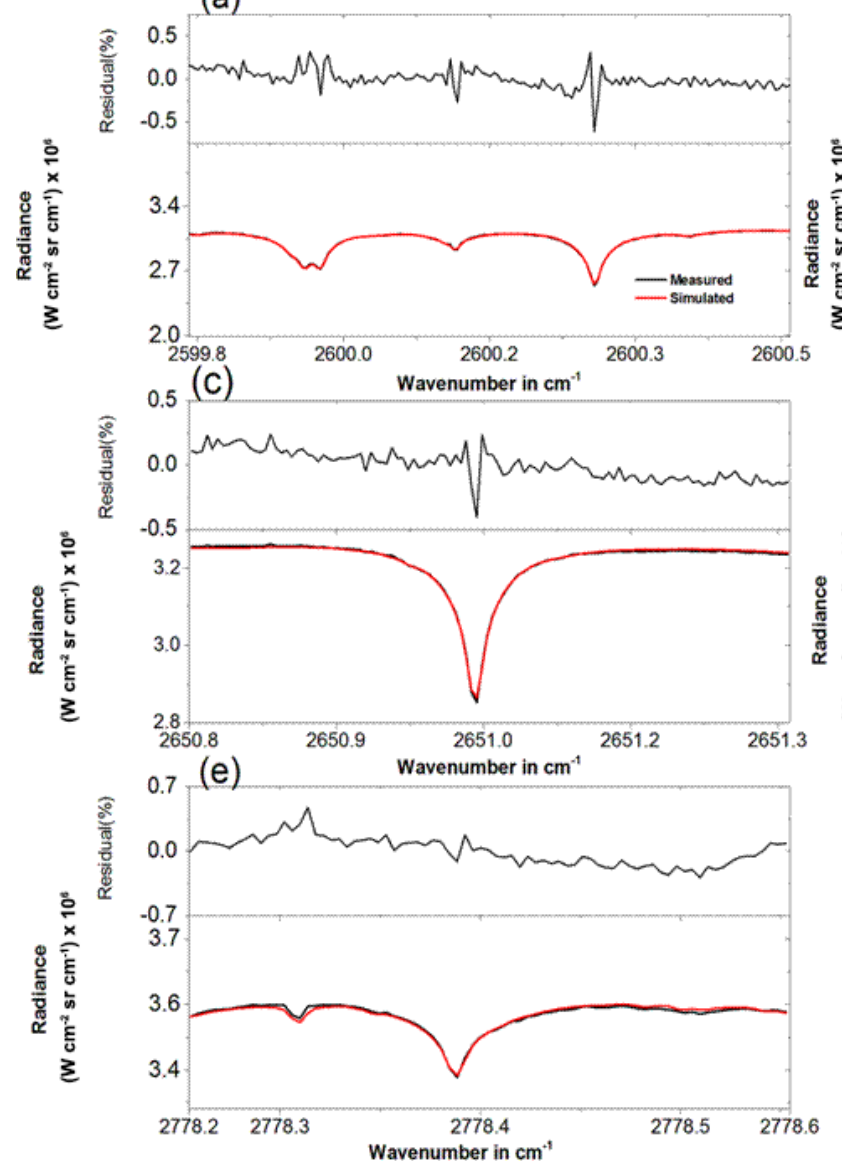

(b)
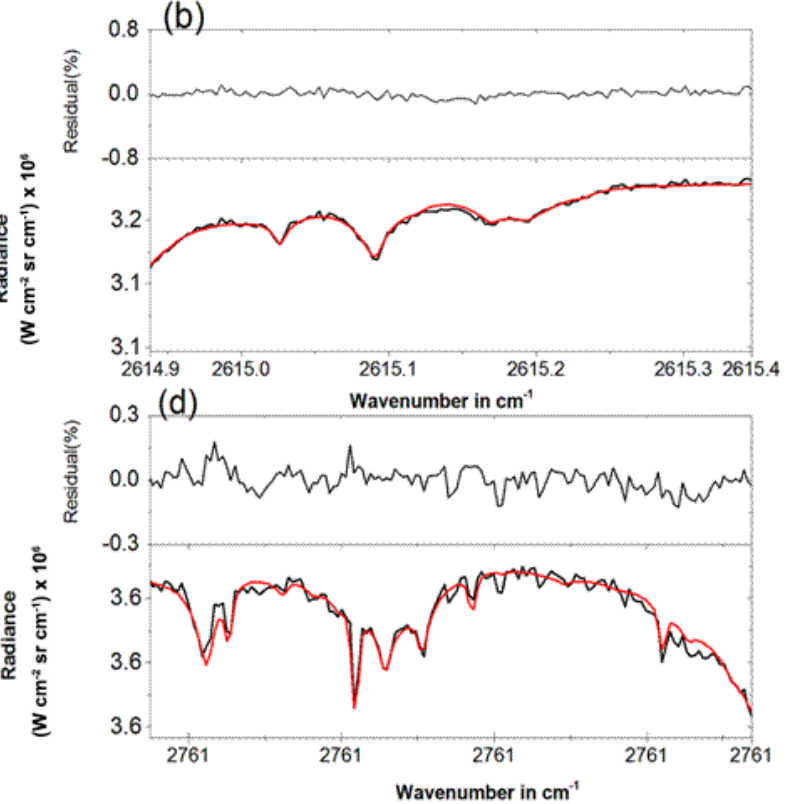

Figure 1. The five spectral microwindows used for retrieval of $\mathrm{CH}_{4}$, with the measured spectrum in red, simulated spectrum in black, and residuals on top of the respective microwindow for spectrum recorded on 26 February 2013; time: $10 \mathrm{~h} 17 \mathrm{~m} 15 \mathrm{~s}$; root mean square (rms) $=0.1189$; solar zenith angle $(\mathrm{SZA})=20.6^{\circ}$; optimal path difference $(\mathrm{OPD})=116.1$; $\mathrm{DOF}=2.23$; field of view $(\mathrm{FOV})=2.27 \mathrm{mrad}$.

sitivity, DOFs, and the contribution of different error sources on measurements, in addition to the spectral residuals that indicate systematic errors in the spectroscopic line data.

\subsection{Vertical resolution and sensitivity assessment}

The spectral resolution of a measurement affects the amount of vertical information derived from the spectral line shape of a measured species (Livesey et al., 2008). Figure 3 shows averaging kernel matrices for the retrieval of the vertical profiles of $\mathrm{CH}_{4}$ and $\mathrm{N}_{2} \mathrm{O}$ mixing ratios, respectively, from the FTIR measurements. The rows of the averaging kernel matrices at selected altitudes which indicate the sensitivity of retrieved $\mathrm{CH}_{4}$ and $\mathrm{N}_{2} \mathrm{O}$ values at the level to true mixing ratios are also presented. The dotted line represents the sum of all the rows of the averaging kernel, which represents the overall sensitivity of the FTIR measurement to observe $\mathrm{CH}_{4}$ and $\mathrm{N}_{2} \mathrm{O}$.

Figure 3 shows a strong sensitivity in the altitude range of the troposphere and lower stratosphere, i.e., 2.45 up to $27 \mathrm{~km}$ for the retrieval of $\mathrm{CH}_{4}$ and $\mathrm{N}_{2} \mathrm{O}$. Thus, the sum of rows of $\mathbf{A}$ for all the retrieval values of $\mathrm{CH}_{4}$ and $\mathrm{N}_{2} \mathrm{O}$ is greater than 0.5 up to $27 \mathrm{~km}$. The trace of the row-averaging kernel for $\mathrm{CH}_{4}$, which is 2.25 for the spectra recorded on 26 February 2013 and $2.11 \pm 0.06$ for all the data, implies that partial columns representing two different altitude ranges in the atmosphere can be obtained from the observations of $\mathrm{CH}_{4}$ in tropical atmospheric conditions. Similarly, the trace of the averaging kernel for $\mathrm{N}_{2} \mathrm{O}$ is $3.38 \pm 0.15$ on for all the data.

The amplitude of the averaging kernels indicates the sensitivity of the retrieval, and the full widths at half maximum (FWHM) indicate the vertical resolution of the corresponding layer. We also ignore the altitude range where the resolution of the instrument is beyond $20 \mathrm{~km}$, which has been computed using the reciprocal of the diagonal values of averaging kernels and multiplying by the intervals of the layers as reported in Rinsland et al. (2005). The vertical resolution is less than $20 \mathrm{~km}$ for altitudes below around $27 \mathrm{~km}$ (not shown). 

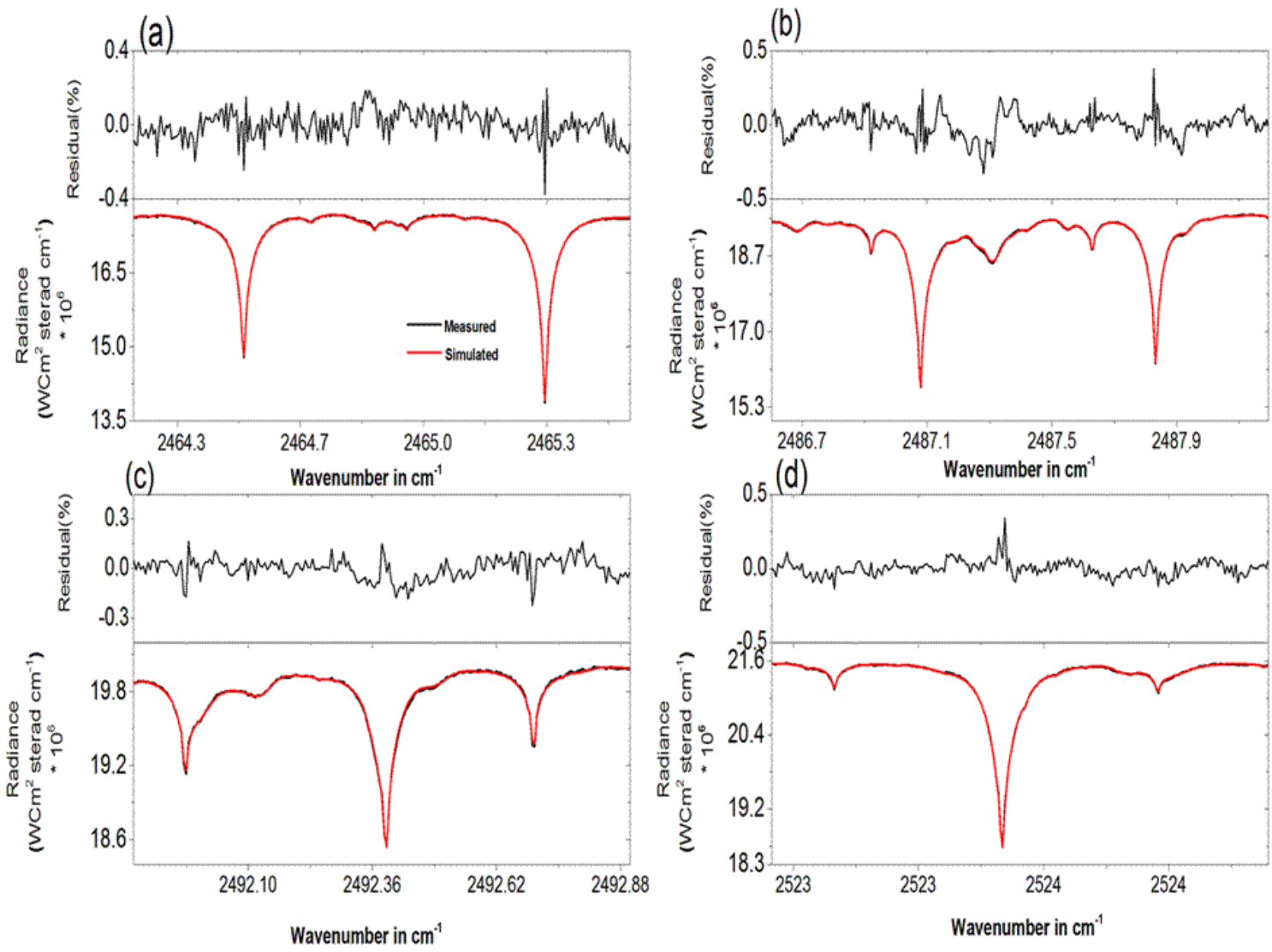

Figure 2. The four spectral microwindows used for retrieval of $\mathrm{N}_{2} \mathrm{O}$, with the measured spectrum in red, simulated spectrum in black, and residuals on top of the respective microwindow for spectrum recorded on 31 December 2009; time: $9 \mathrm{~h} 3 \mathrm{~m} 27 \mathrm{~s}$; solar zenith angle $(\mathrm{SZA})=13.4^{\circ}$; optimal path difference $(\mathrm{OPD})=100 ; \mathrm{DOF}=3.35$.

(a)

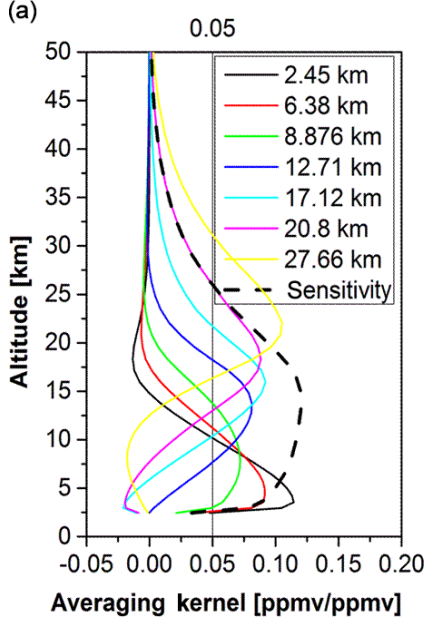

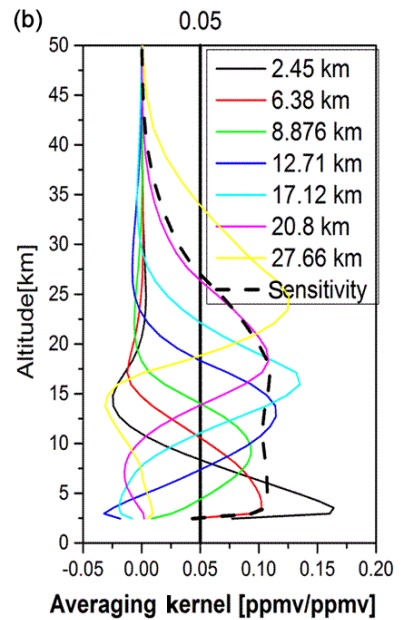

Averaging kernel [ppmv/ppmv]

Figure 3. Sensitivity analysis of the retrieved profiles of (a) $\mathrm{CH}_{4}$ and (b) $\mathrm{N}_{2} \mathrm{O}$ at Addis Ababa using the selected rows of the averaging kernels as a function of altitude. The dotted lines are the sum of the rows of averaging kernels for a spectrum measured on 26 February 2013 for $\mathrm{CH}_{4}$ and 31 December 2009 for $\mathrm{N}_{2} \mathrm{O}$.

\subsection{Error estimation}

The error calculations conducted here are based on the error estimation package incorporated in the PROFFIT retrieval algorithm that was developed based on the analytical method suggested by Rodgers (2000). The quantified sources of errors are temperature, measurement noise, instrumental line shape, solar lines, line of sight, zero level baselines offset, and spectroscopy. It has been observed that baseline and atmospheric temperature uncertainties are the leading contribution to the total uncertainty. Details about the evaluation of individual contributions to the error budget are provided in Senten et al. (2008). Figure 4 shows the statistical (random) error, systematic error, and total fractional error (left to right) for $\mathrm{CH}_{4}$ (top) and $\mathrm{N}_{2} \mathrm{O}$ (bottom) retrieval from a spectrum recorded on 26 February 2013 and 31 December 2009, respectively. It can be noted from Fig. 4 that the main systematic error source is the uncertainty in spectroscopic parameters, whereas the major statistical error source is the baseline. Random errors are dominated by the baseline offset uncertainty and the measurement noise in the troposphere. Total estimated random error due to parameter uncertainties is depicted as a dark-yellow line (see Fig. 4a). The total statisti- 


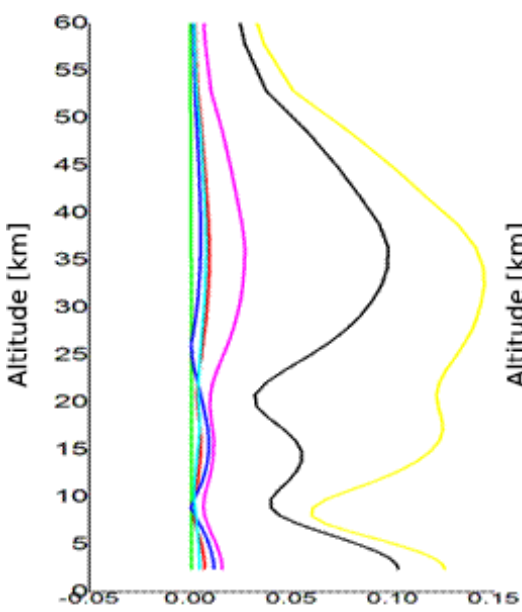

(a) Statistical error [ppm]

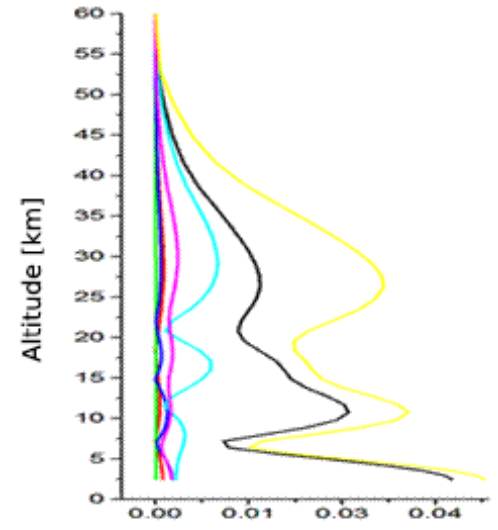

(a) Statstical error [ppm]

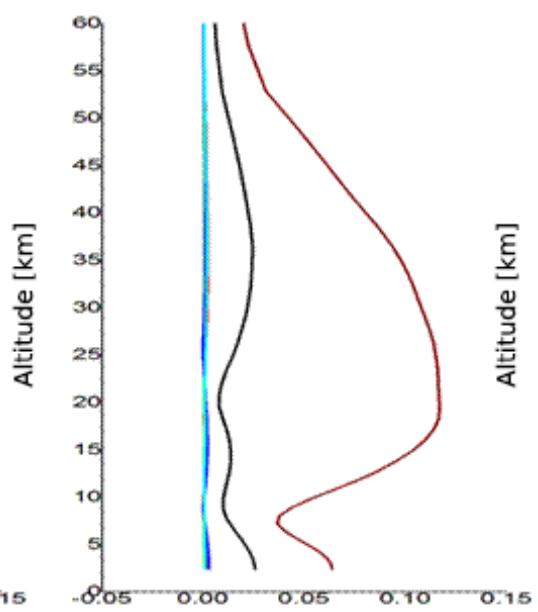

(b) Systematic error [ppm]

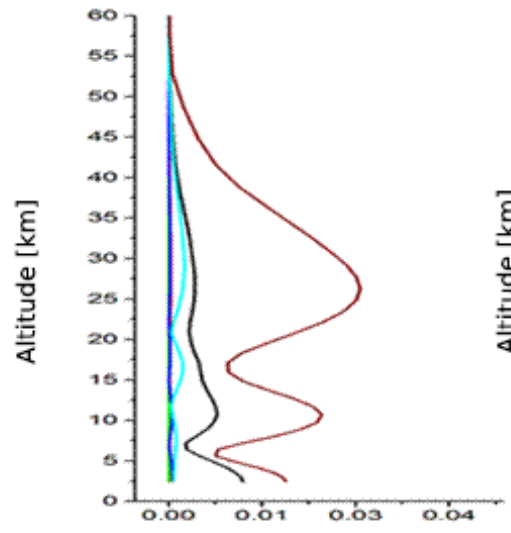

(b) Systematic error [ppm]

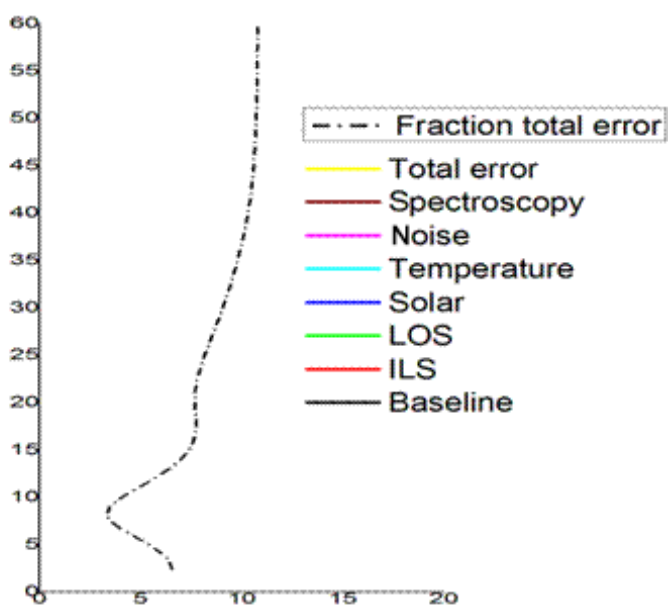

(c) Fraction total error [\%]

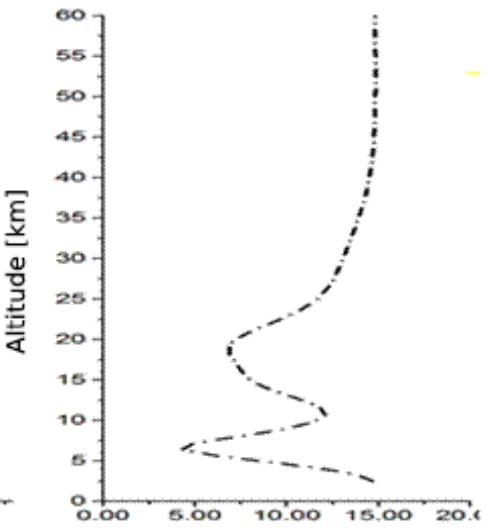

(c) Fraction total error [\%]

Figure 4. Estimated errors for the profiling retrieval of $\mathrm{CH}_{4}$ (top) and $\mathrm{N}_{2} \mathrm{O}$ (bottom) over Addis Ababa: (a) statistical (random) errors (b) systematic errors of parameter listed in the legends, and (c) fractional total error (\%).

cal error of $\mathrm{CH}_{4}$ retrieval is about 0.07 ppmv (4.4\%) in the lower troposphere and about $0.04 \mathrm{ppmv}(2.25 \%)$ in the upper troposphere/lower stratosphere (UT/LS) region. Concerning systematic errors, spectroscopic parameters are the dominant uncertainty sources, and estimated total systematic error is about $0.05 \mathrm{ppmv}(3.5 \%)$ and $0.1 \mathrm{ppmv}(7.2 \%)$ for the lower troposphere and the UT/LS region, respectively.

Figure $4 \mathrm{a}-\mathrm{c}$ (bottom panels) show the estimated random and systematic errors for the $\mathrm{N}_{2} \mathrm{O}$ profile retrieved from FTIR. Random errors are dominated by the baseline offset uncertainty and temperature in the troposphere. The total statistical errors in the middle and upper troposphere are between $0.009(3.5 \%)$ and $0.03 \mathrm{ppmv}(9 \%)$, with its major contribution from the baseline. Spectroscopic parameters and baselines are the dominant uncertainty sources for systematic errors. The estimated total systematic error is less than $0.025 \mathrm{ppmv}(8 \%)$ at altitudes below $22 \mathrm{~km}$. The total fractional error of $\mathrm{CH}_{4}$ and $\mathrm{N}_{2} \mathrm{O}$ retrieved from ground-based FTIR has been shown in the last column of Fig. 4. Fractional error of $\mathrm{CH}_{4}$ is less than $10 \%$ at altitudes below $27 \mathrm{~km}$ with minimum fractional error of $4 \%$ at middle troposphere. On the other hand, the total fraction error of $\mathrm{N}_{2} \mathrm{O}$ retrieval is less than $13 \%$ at altitudes below $27 \mathrm{~km}$, with a minimum value of $4 \%$ at $6 \mathrm{~km}$ and $7.5 \%$ at $17 \mathrm{~km}$.

\section{Time series partial-column amount}

Concentrations of $\mathrm{CH}_{4}$ and $\mathrm{N}_{2} \mathrm{O}$ were derived from 166 spectra of NDACC filter 3 recorded from May 2009 to March 2013. Figure 5 shows the time series of the retrieved total column amounts (in molecules $\mathrm{cm}^{-2}$ ) of $\mathrm{CH}_{4}$ and $\mathrm{N}_{2} \mathrm{O}$ obtained from the Addis Ababa FTIR measurement site from 2009 to 2013. The mean total column amounts of $\mathrm{CH}_{4}$ and $\mathrm{N}_{2} \mathrm{O}$ measured at Addis Ababa are $2.9 \times 10^{19}$ molecules $\mathrm{cm}^{-2} \pm 3.4 \%$ and $5.23 \times$ $10^{18}$ molecules $\mathrm{cm}^{-2} \pm 6.93 \%$, respectively. Due to sensitivity of the observation in measuring $\mathrm{CH}_{4}$ and $\mathrm{N}_{2} \mathrm{O}$ trace gases being limited to an altitude of around $27 \mathrm{~km}$ as explained using averaging kernel row of the measurement, the mean partial column of $\mathrm{CH}_{4}$ and $\mathrm{N}_{2} \mathrm{O}$ 
(a)

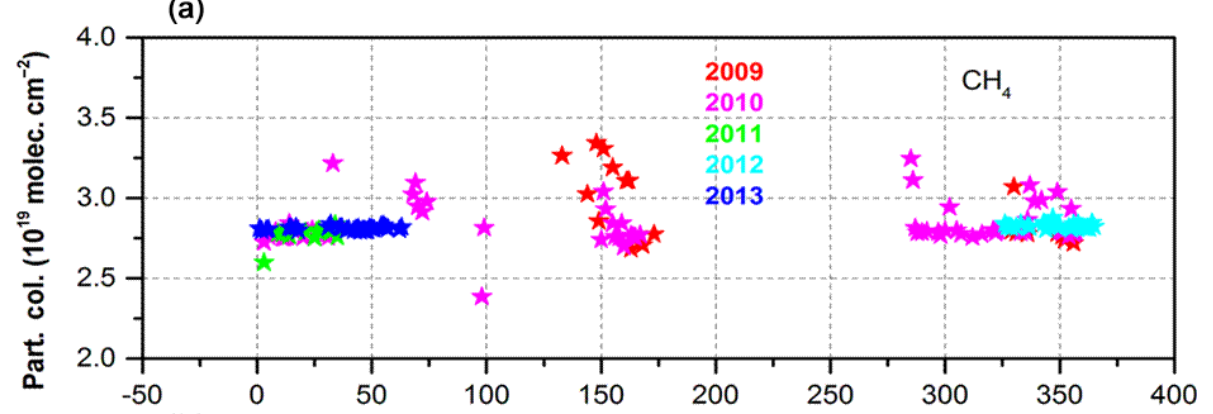

(b)

Day of year

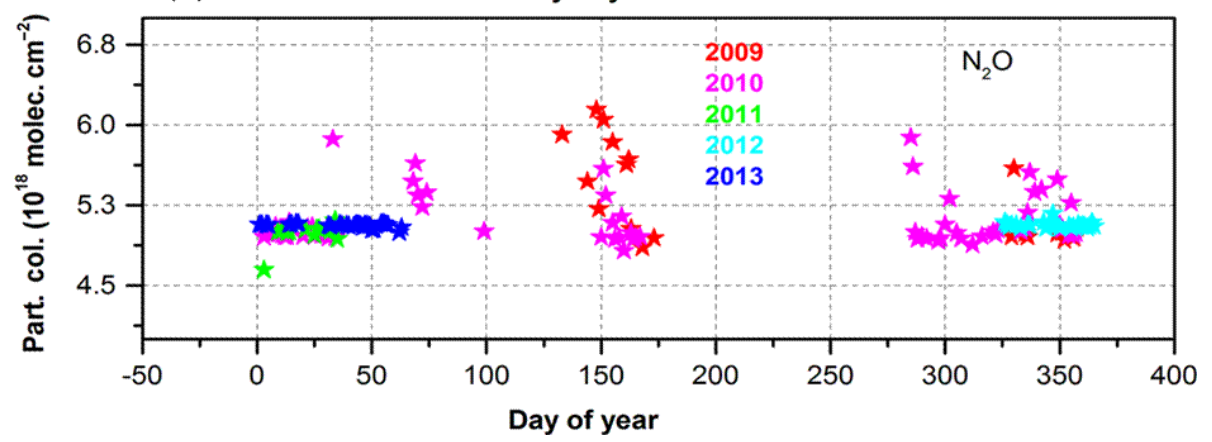

Figure 5. Partial columns of (a) $\mathrm{CH}_{4}$ and (b) $\mathrm{N}_{2} \mathrm{O}$ gases over Addis Ababa in the altitude range of 2.45 to $27 \mathrm{~km}$.

within the sensitivity range of the instrument are determined as $2.85 \times 10^{19}$ molecules $\mathrm{cm}^{-2} \pm 5.3 \%$ and $5.16 \times$ $10^{18}$ molecules $\mathrm{cm}^{-2} \pm 6.95 \%$, respectively.

The sensitivity from the averaging kernel analysis is used to determine the upper altitude limit up to which $\mathrm{CH}_{4}$ and $\mathrm{N}_{2} \mathrm{O}$ data from ground-based FTIR can reasonably be used. The DOFs within these partial-column limits are about 1.03 and 1.27 for $\mathrm{CH}_{4}$ and $\mathrm{N}_{2} \mathrm{O}$, respectively. Error analysis indicates that the statistical error accounts for $2.3 \%$ in the total column amounts of $\mathrm{CH}_{4}$ and $2.0 \%$ in total columns of $\mathrm{N}_{2} \mathrm{O}$. Similarly, the systematic error accounts for $2.1 \%$ in the total columns of $\mathrm{CH}_{4}$ and $2.26 \%$ in the total columns of $\mathrm{N}_{2} \mathrm{O}$. Generally, the overall contribution of both statistical and systematic errors to the total error during the retrieval of $\mathrm{CH}_{4}$ and $\mathrm{N}_{2} \mathrm{O}$ from ground-based FTIR are $3.1 \%$ and $3 \%$, respectively.

\section{Satellite measurements}

\subsection{Michelson Interferometer for Passive Atmospheric Sounding (MIPAS)}

Michelson Interferometer for Passive Atmospheric Sounding (MIPAS) is a Fourier transform spectrometer for the detection of limb emission spectra from the upper atmosphere to the lower thermosphere and is designed for global vertical profile measurement of many atmospheric trace constituents relevant to the atmospheric chemistry, dynamics, and radiation budget of the middle atmosphere. The verti- cal resolution of MIPAS ranges from 2.5 to $7 \mathrm{~km}$ for $\mathrm{CH}_{4}$ and from 2.5 to $6 \mathrm{~km}$ for $\mathrm{N}_{2} \mathrm{O}$ in the reduced-resolution period (Plieninger et al., 2015). In this study, we have used the reduced spectral resolution Institute of Meteorology and Climate Research/Instituto de Astrofísica de Andalucía (IMK/IAA) MIPAS methane and nitrous oxide data products V5R_CH4_224 and V5R_N2O_224 (Plieninger et al., 2016, 2015). MIPAS profile points, with the diagonal element of the averaging kernels above 0.03 and the visibility flag of 1 , have been used (Plieninger et al., 2016).

\subsection{Microwave Limb Sounder (MLS)}

The Earth Observing System (EOS) Microwave Limb Sounder (MLS) is one of four instruments on NASA's EOS Aura satellite, launched on 15 July 2004, into a near-polar, sun-synchronous orbit at $705 \mathrm{~km}$ altitude (Schoeberl et al., 2006). It measures $\mathrm{N}_{2} \mathrm{O}$ in spectral region, $640 \mathrm{GHz}$ from the stratosphere into upper troposphere (Waters, 2006). Moreover, spatial coverage of this instrument is nearly global $\left(-82^{\circ} \mathrm{S}\right.$ to $\left.82^{\circ} \mathrm{N}\right)$, and individual profiles are spaced horizontally by $1.5^{\circ}$ or $165 \mathrm{~km}$ along the orbit track. Roughly, the satellite covers these latitudinal bands with 15 orbits per day or around 3500 profiles per day with vertical resolution of 4-6 km for $\mathrm{N}_{2} \mathrm{O}$. This instrument ascends in the equatorial region at local time of around 13:45 LT.

MLS $\mathrm{N}_{2} \mathrm{O}$ data set has been used to validate the groundbased FTIR measurements. However, methane $\left(\mathrm{CH}_{4}\right)$ data are derived using coincident measurements of atmospheric water vapor $\left(\mathrm{H}_{2} \mathrm{O}\right)$, carbon monoxide $(\mathrm{CO})$, and nitrous ox- 
ide $\left(\mathrm{N}_{2} \mathrm{O}\right)$ from the EOS MLS instrument on the NASA Aura satellite, and details are given in Minschwaner and Manney (2015). Selection criteria were implemented as stated in Livesey et al. (2013). More details regarding the MLS experiment and data screening are provided in the above references in detail and at https://mls.jpl.nasa.gov/data/datadocs. php (last access: 21 July 2020). MLS $\mathrm{N}_{2} \mathrm{O}$ v2.2 has been validated, and its precision and accuracy is in Lambert et al. (2007). The authors reported that MLS $\mathrm{N}_{2} \mathrm{O}$ precision is $24-14$ ppbv (9\%-41\%) and the accuracy is $70-3$ ppbv (9\%$25 \%$ ) in the pressure range of $100-4.6 \mathrm{hPa}$.

\subsection{Atmospheric Infrared Sounder (AIRS)}

Operating in nadir sounding geometry, the Atmospheric Infrared Sounder (AIRS) on board the Aqua satellite launched into Earth orbit in May 2002 (Chahine et al., 2006). AIRS is a medium-resolution infrared grating spectroradiometer, and a diffraction grating disperses the incoming infrared radiation into 17 linear detector arrays comprising 2378 spectral samples. The satellite crosses the Equator at approximately 01:30 and 13:30 local time, resulting in near-global coverage twice a day. AIRS has 2378 channels that cover from 649 to 1136 , 1217 to 1613 , and 2169 to $2674 \mathrm{~cm}^{-1}$. It also measures trace gases such as $\mathrm{O}_{3}, \mathrm{CO}$, and to some extent $\mathrm{CO}_{2}$. AIRS $\mathrm{CH}_{4}$ and $\mathrm{N}_{2} \mathrm{O}$ retrievals have been characterized and validated by Xiong et al. (2008, 2014), respectively. Both AIRS and MLS data were obtained through the Goddard Earth Sciences Data and Information Services Center (https://daac.gsfc.nasa.gov/, last access: 21 July 2020).

\section{Comparison of FTIR with MIPAS, MLS, and AIRS observations}

\subsection{Comparison methodology}

The quality of FTIR $\mathrm{CH}_{4}$ and $\mathrm{N}_{2} \mathrm{O}$ for a period that covers May 2009 to March 2013 is assessed through comparison with data from MIPAS (May 2009 to December 2010), MLS (May 2009 to March 2013), and AIRS (May 2009 to March 2013) sensors on board satellites. MIPAS, MLS, and AIRS retrievals were used after averaging data obtained within coincident criteria of $\pm 2^{\circ}$ of latitude and $\pm 10^{\circ}$ of longitude from the ground-based FTIR site in Addis Ababa and within time difference of $\pm 24 \mathrm{~h}$. The more stringent latitudinal criterion has proven to be a good choice for all comparisons, since latitudinal variations are, in general, more pronounced than longitudinal ones (Takele Kenea et al., 2013). These criteria yielded 29, 77, and $118 \mathrm{~d}$ of coincident measurements between FTIR and MIPAS, MLS, and AIRS, respectively.

The ground-based FTIR measurements of $\mathrm{CH}_{4}$ and $\mathrm{N}_{2} \mathrm{O}$ have been validated at different locations (e.g., Senten et al., 2008). The satellite data (MIPAS, MLS, and AIRS) have a considerably better vertical resolution than ground-based
FTIR profiles due to observation geometry, spectral windows, and measurement techniques. Thus, analysis of the comparison between volume mixing ratio values derived from FTIR and MIPAS were performed for the data sets collected on May 2009 to December 2010. Furthermore, the comparison of FTIR $\left(\mathrm{CH}_{4}\right.$ and $\left.\mathrm{N}_{2} \mathrm{O}\right)$ with MLS $\left(\mathrm{CH}_{4}\right.$ and $\left.\mathrm{N}_{2} \mathrm{O}\right)$ and AIRS $\left(\mathrm{CH}_{4}\right)$ for the time period of May 2009 to February 2013 has also been applied to assess quality of the data derived from FTIR. Hence, the profiles from MIPAS, MLS, and AIRS have been smoothed to make a comparison with FTIR as satellite observations attain better vertical resolution. Therefore, the satellite measurement profiles are smoothed using the FTIR averaging kernels of individual species obtained from the ground-based FTIR retrieval by applying the procedures reported in Rodgers and Connor (2003) and given as

$\boldsymbol{x}_{\mathrm{si}}=\boldsymbol{x}_{\mathrm{a}}+\mathbf{A}\left(\boldsymbol{x}_{i}-\boldsymbol{x}_{\mathrm{a}}\right)$,

where $\boldsymbol{x}_{\mathrm{si}}$ is the smoothed profile, $\boldsymbol{x}_{\mathrm{a}}$ and $\mathbf{A}$ represent the a priori and averaging kernel for $\mathrm{CH}_{4}$ and $\mathrm{N}_{2} \mathrm{O}$ obtained from the ground-based FTIR instrument, respectively, and $\boldsymbol{x}_{i}$ is the retrieved profile obtained from satellite measurements after we interpolated it to the FTIR grid spacing. We also calculate the following error statistics that can characterize the features of the instruments and parameters to be observed, such as the bias between the instruments using the difference (absolute or relative) in the daily mean profile. The difference (absolute or relative) at each altitude layers of a pair of profile is calculated using

$\delta_{i}(z)=\left[\operatorname{FTIR}_{i}(z)-\mathbf{x}_{\mathrm{si}}(z)\right]$.

The mean squares error can be expressed as

$\operatorname{MSE}_{i}(z)=\sqrt{\frac{1}{N(z)-1} \sum_{i=1}^{N(Z)}\left[\delta_{i}(z)\right]^{2}}$.

The mean difference (absolute or relative) for a complete set of coincident pair profiles obtained from the ground-based FTIR and the correlative satellites is expressed as

$\triangle_{\mathrm{rel}}(z)=100(\%) \times \frac{1}{N(z)} \sum_{i=1}^{N(z)} \frac{\left[\operatorname{FTIR}_{i}(z)-\boldsymbol{x}_{\mathrm{si}}(z)\right]}{\left[\operatorname{FTIR}_{i}(z)+\boldsymbol{x}_{\mathrm{si}}(z)\right] / 2}$,

where $\delta_{i}(z)$ is the difference (absolute or relative), $N(z)$ is the number of coincidences at $z$, and $\operatorname{FTIR}_{i}(z)$ is the FTIR VMR at $z$ and the corresponding $\boldsymbol{x}_{\mathrm{si}}(z)$ volume mixing ratio derived from satellite instruments. The standard deviation from the mean differences (absolute or relative) $\sigma_{\text {diff }}(z)$ is important to partially characterize the measurement error. As reported in von Clarmann (2006), some use debiased standard deviation, which measures the combined precision of the instruments instead of the standard deviation of the mean 
differences.

$\sigma_{\text {diff }}(z)=\sqrt{\frac{1}{N(z)-1} \sum_{i=1}^{N(Z)}\left[\delta_{i}(z)-\triangle_{\mathrm{abs}}(z)\right]^{2}}$,

where $\delta_{i}(z)$ is the difference (absolute or relative) for the $i$ th coincident pair calculated using Eq.(4). The statistical uncertainty in the mean differences (absolute or relative), which is standard error of the mean (SEM), is the quantity used to judge the statistical significance of the estimated biases, and it can be expressed in terms of the standard deviation of the mean as follows:

$\operatorname{SEM}(Z)=\frac{\sigma(z)}{\sqrt{N(Z)}}$

One can also conduct the comparison of FTIR and MIPAS using partial columns obtained from both FTIR and smoothed MIPAS $\mathrm{CH}_{4}$ and $\mathrm{N}_{2} \mathrm{O}$. Hence, the relative difference between ground-based FTIR and smoothed MIPAS partial columns of $\mathrm{CH}_{4}$ and $\mathrm{N}_{2} \mathrm{O}$ by taking into account the lower altitude limit of MIPAS observations and upper limit of ground-based FTIR sensitivity has been calculated using

$\operatorname{RDiff}(\%)=100 \times\left[\frac{\left(\operatorname{PC}_{\mathrm{FTIR}}(z)-\mathrm{PC}_{\mathrm{Sat}}(z)\right)}{\left(\operatorname{PC}_{\mathrm{FTIR}}(z)+\mathrm{PC}_{\mathrm{Sat}}(z)\right) / 2}\right]$,

where PC is a partial column of FTIR and the corresponding satellite measurements. Here in this paper coincidence and smoothing errors are not taken into account in the full error analysis of the comparisons between remotely sensed data sets (von Clarmann, 2006). Hence, we focus on the random uncertainties in each instrument (Combined random error) that has been used to evaluate the comparison uncertainty (standard deviation of the difference).

\subsection{Comparison of FTIR $\mathrm{CH}_{4}$}

In Fig. 6, mean profiles, mean differences, and estimated errors versus deviations of the difference between FTIR and MIPAS_CH4_224 mixing ratios are shown. The comparison has been made using 29 coincident data for a time period between November 2009 and December 2010. Figure 6b indicates a negative bias of $-4.8 \%$ at around $16 \mathrm{~km}$ and $2 \%$ at $22 \mathrm{~km}$. Between 23 and $27 \mathrm{~km}$, the FTIR value is higher than MIPAS values. The difference increases with altitude from 23 to $27 \mathrm{~km}(4.6 \%)$ with a maximum at $27 \mathrm{~km}$. A large negative bias in FTIR $\mathrm{CH}_{4}$ is obtained; i.e., FTIR $\mathrm{CH}_{4}$ values are lower by $0.07(4.8 \%)$ to $0.04 \mathrm{ppmv}(2.2 \%)$.

Figure $6 \mathrm{a}$ indicates that the standard deviation of the mean differences is larger than the combined random error of the two instruments throughout the altitude range. For instance, it is twice the combined standard deviation at altitudes above $20 \mathrm{~km}$ and less below $20 \mathrm{~km}$, which indicates the underestimation of random errors from one or both of the instruments. In addition, the overestimation of standard deviation of the difference may result from not taking all the error budget of MIPAS into account, and the spatial and temporal criteria sets used to collect the coincidence data of MIPAS can create a discrepancy as well. The natural variations in the methane have also contributed to the overestimation of a standard deviation of the difference, as biases vary with seasons as reported in Payan et al. (2009).

Figure $7 \mathrm{~b}$ shows the comparison between FTIR $\mathrm{CH}_{4}$ profiles and $\mathrm{CH}_{4}$ derived from MLS measurements of atmospheric water vapor $\left(\mathrm{H}_{2} \mathrm{O}\right)$, carbon monoxide $(\mathrm{CO})$, and nitrous oxide $\left(\mathrm{N}_{2} \mathrm{O}\right)$ and indicates that no significant bias in FTIR $\mathrm{CH}_{4}$ data is present between 18 and $20 \mathrm{~km}$. In the tropopause layer, the comparison indicates a negative bias of $-1.7 \%$ at $17 \mathrm{~km}$; i.e., the FTIR value is slightly high. FTIR $\mathrm{CH}_{4}$ values are lower at altitudes between 20 and $27 \mathrm{~km}$ with a bias of below $11 \%$, which is maximum at $27 \mathrm{~km}$ or on average by 0.12 ppmv $(6.7 \%)$ between 20 and $27 \mathrm{~km}$. The bias below $19 \mathrm{~km}$ and above $27 \mathrm{~km}$ can not be explained by the systematic errors of FTIR as the bias is larger than the systematic errors of FTIR. However, the latter, which is for altitudes above $27 \mathrm{~km}$, is also out of the sensitivity ranges of FTIR. Furthermore, the standard deviation of the difference is larger than the combined random errors of the instruments. A bias in the altitude range of 20 to $27 \mathrm{~km}$ can be explained by the systematic error of FTIR.

In Fig. 8 mean profiles, differences, and estimated error versus deviation of the difference between FTIR and AIRS mixing ratios are shown. The largest negative bias is found at altitudes between 11 and $19 \mathrm{~km}$, with a maximum difference of $-0.08 \mathrm{ppmv}$ at around $15 \mathrm{~km}$. A negative bias of the AIRS mixing ratio of $\mathrm{CH}_{4}$ is higher than that the FTIR as shown in Fig. 8. A positive bias existed at altitudes between 7 and $9 \mathrm{~km}$, and similarly, it also has been shown at altitudes between 21 and $27 \mathrm{~km}$, with a maximum value at around $27 \mathrm{~km}$, and its bias is $0.14 \mathrm{ppmv}(9 \%)$. The standard deviation of the difference agrees with the combined random error at altitudes below $20 \mathrm{~km}$, and it overestimates above $20 \mathrm{~km}$.

In all the comparisons of FTIR $\mathrm{CH}_{4}$ with data from MIPAS, MLS, and AIRS, sensors on board satellites indicate a negative bias below $21 \mathrm{~km}$ and a positive bias above $21 \mathrm{~km}$, with similar bias of not higher than $5.8 \%$ in the altitude range of $21-27 \mathrm{~km}$ (see Table 2.). The volume mixing ratios derived from the satellite are higher at altitudes lower than $21 \mathrm{~km}$.

\subsection{Comparison of FTIR $\mathrm{N}_{2} \mathrm{O}$}

FTIR $\mathrm{N}_{2} \mathrm{O}$ mixing ratio MIPAS comparison results are shown in Fig. 9, where it represents the mean profiles, mean absolute difference, and standard deviation of the mean along with the combined errors of the two instruments. Mean profiles of FTIR show a maximum at around $23 \mathrm{~km}$ and decrease smoothly as altitude increases, and that of the MIPAS_N2O_224 value starts to decline starting from the lowermost stratosphere. 

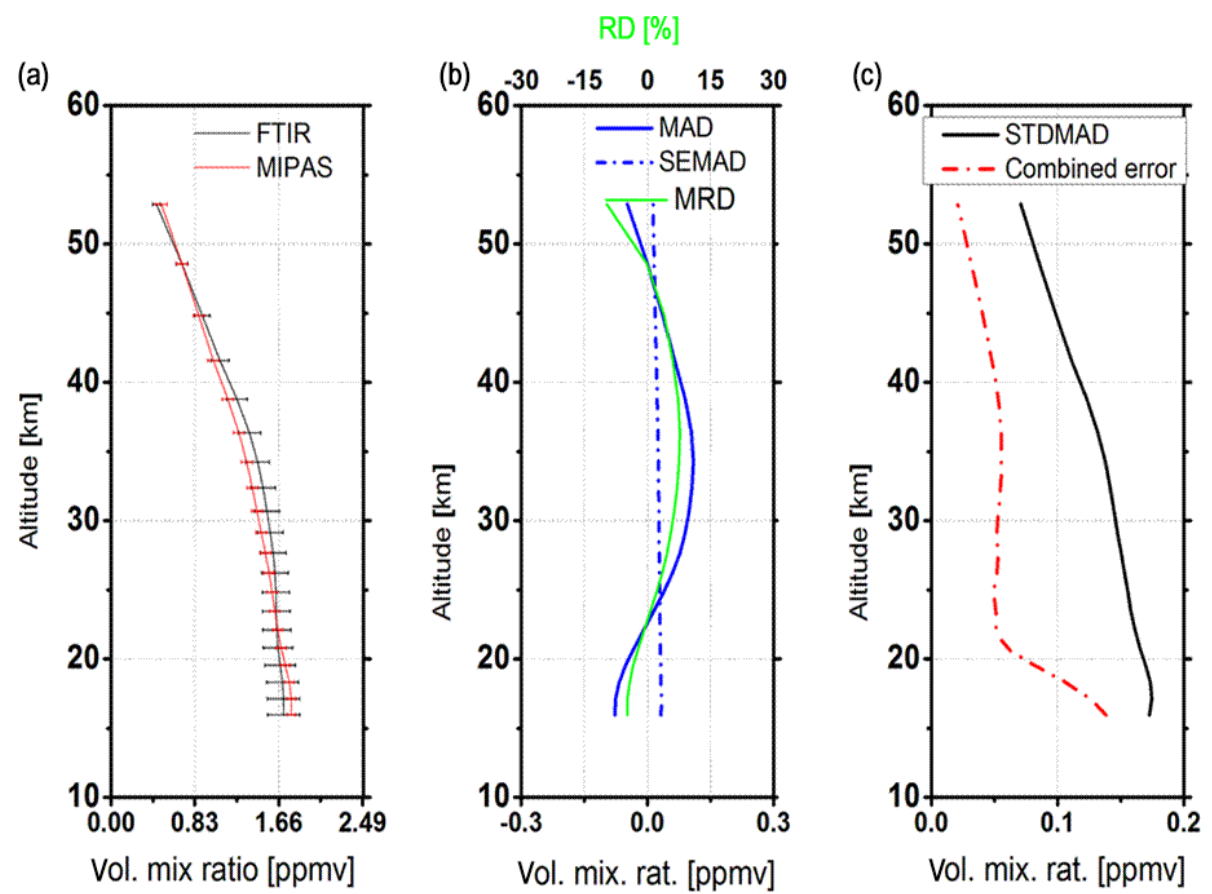

Figure 6. Comparison of $\mathrm{CH}_{4}$ from MIPAS reduced resolution (V5R_CH4_224) and FTIR. (a) Mean profiles of MIPAS (red) and FTIR (black) and their standard deviation (horizontal bars). (b) Mean difference FTIR minus MIPAS (MAD, solid blue), standard error of the difference (SEMAD; dotted blue), and mean relative differences FTIR minus MIPAS relative to their average (MRD; green, upper axis). (c) Combined mean estimated statistical error of the difference (combined error, dotted red, contains MIPAS instrument noise error, and FTIR random error budget) and standard deviation of the difference (STDMAD; solid black).
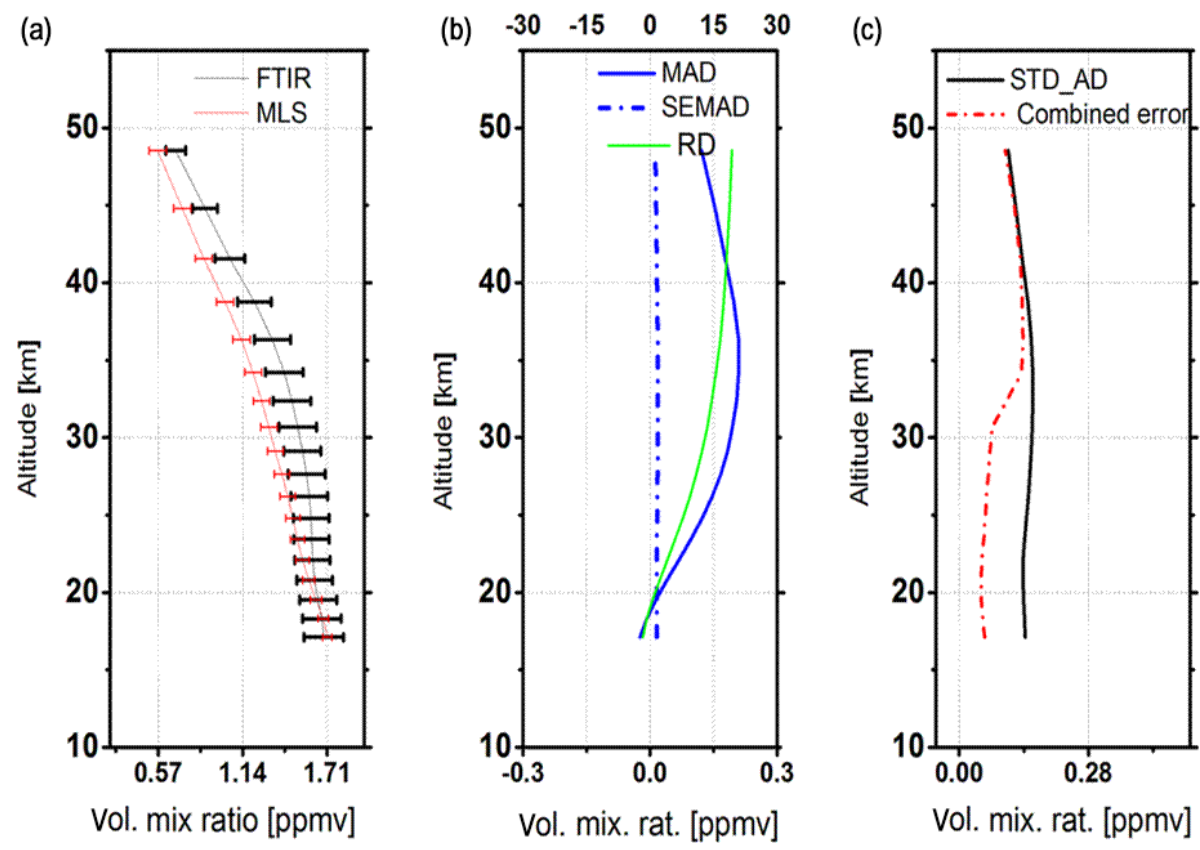

Figure 7. Comparison of $\mathrm{CH}_{4}$ from MLS (V3.3) and FTIR. Details as in Fig. 11. 
(a)

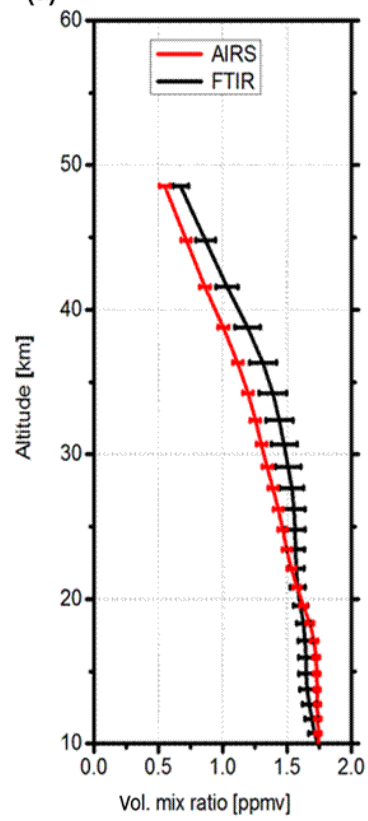

(b)

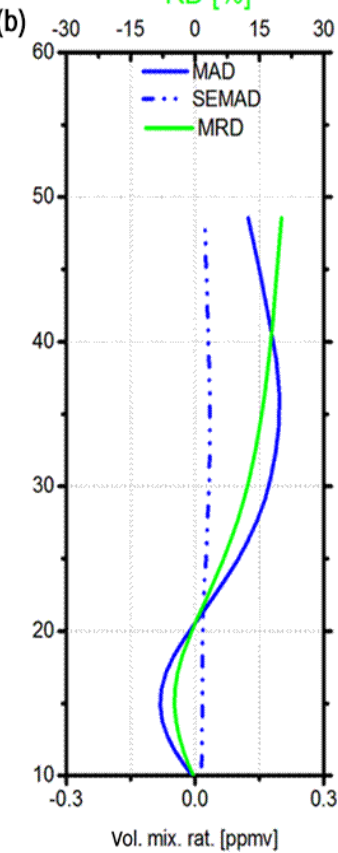

(c)

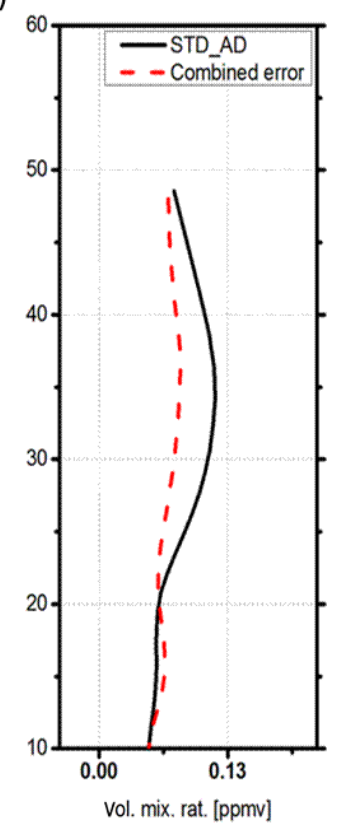

Figure 8. Comparison of $\mathrm{CH}_{4}$ from AIRS and FTIR. Details as in Fig. 11.

Table 2. Averaged statistical means $(M)$ and standard deviations $(\mathrm{SD})$ of the relative differences $100 \times\left[\frac{\text { FTIR-MIPAS }}{\frac{\text { FTIR+MIPAS }}{2}}\right](\%)$ defined in the altitude range of 17-20 and 21-27 km. The numbers of coincidences $(N)$ within a spatiotemporal criterion of $\pm 2^{\circ}$ of latitude and $\pm 10^{\circ}$ of longitude and time difference of $\pm 24 \mathrm{~h}$ are selected for intercomparison. This is for FTIR $\mathrm{CH}_{4}$ and $\mathrm{N}_{2} \mathrm{O}$ with the corresponding other instruments (stated in second column).

\begin{tabular}{llrrlr}
\hline Gas & Instrument & Altitude range & $M \pm$ SD & Period & $N$ \\
\hline $\mathrm{CH}_{4}$ & MIPAS & $17-20 / 21-27$ & $-4.8 / 4.2 \pm 5.2 / 5.5$ & May 2009-Dec 2010 & 29 \\
& MLS & $17-19 / 20-27$ & $-1.8 / 5.8 \pm 8 / 8.8$ & Jun 2009-Feb 2013 & 77 \\
& AIRS & $17-20 / 21-27$ & $-2.8 / 5.3 \pm 3.5 / 5.4$ & Jun 2009-Feb 2013 & 118 \\
\hline
\end{tabular}

Comparison of FTIR $\mathrm{N}_{2} \mathrm{O}$ profiles to MIPAS (V5R_N2O_224) measurements (see Fig. 9b) indicates that FTIR value is higher than the MIPAS above $20 \mathrm{~km}$, and the maximum mean absolute difference in $\mathrm{N}_{2} \mathrm{O}$ is $15 \%$ ( 0.04 ppmv) at around $24 \mathrm{~km}$, while the FTIR value is less at altitudes below $20 \mathrm{~km}$, with a maximum difference of $-7 \%$ $(-0.02 \mathrm{ppmv})$ at around $17 \mathrm{~km}$. The bias at $19 \mathrm{~km}$ is not statistically significant, as the standard error of the mean is larger than the bias. In the remaining altitudes, standard error of the mean is smaller than the mean bias, and the biases are statistically significant. Since, the bias at altitudes between 20 and $27 \mathrm{~km}$ is smaller than the FTIR systematic errors, the bias could be explained in terms of systematic uncertainties in FTIR (see Fig. 4b, bottom panel). The standard deviation of the difference is larger than the combined error of the two instruments at altitudes above $20 \mathrm{~km}$ (see Fig. 9c), and the standard deviation of the difference agrees with the estimated combined random error in the altitude ranges between 20 and $27 \mathrm{~km}$. For the altitudes below $20 \mathrm{~km}$, the estimated combined random error is overestimated.

Figure $10 \mathrm{a}$ represents the mean profiles of $\mathrm{N}_{2} \mathrm{O}$ derived from the coincident pairs of FTIR and MLS. Throughout the whole altitude range, the value derived from FTIR is overestimated (relative to MLS). The FTIR values of $\mathrm{N}_{2} \mathrm{O}$ are larger than the MLS value of $\mathrm{N}_{2} \mathrm{O}$ by a factor of 1.2 and 1.1 at around 21 and $27 \mathrm{~km}$, respectively. The mean relative difference in FTIR and MLS $\mathrm{N}_{2} \mathrm{O}$ value increases as altitude increases; its value is less than $18.6 \%$ at altitudes below $27 \mathrm{~km}$, and its bias below $22 \mathrm{~km}$ is less than $8 \%$, which can be explained in terms of the systematic error of FTIR $\mathrm{N}_{2} \mathrm{O}$. Thus, the positive bias is statistically significant as the mean difference in the comparison is larger than the standard error of the mean. 
(a)

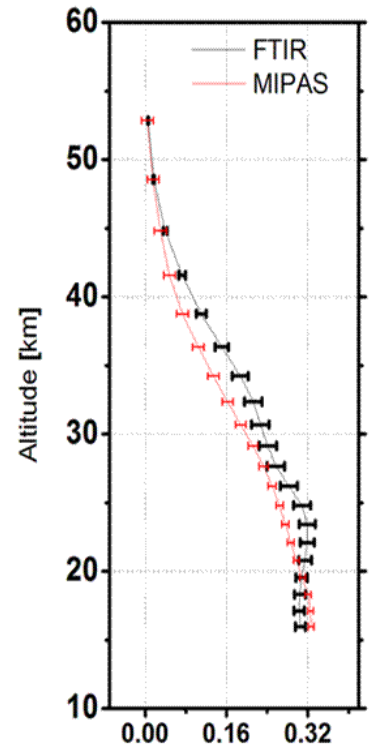

Vol. mix ratio [ppmv]

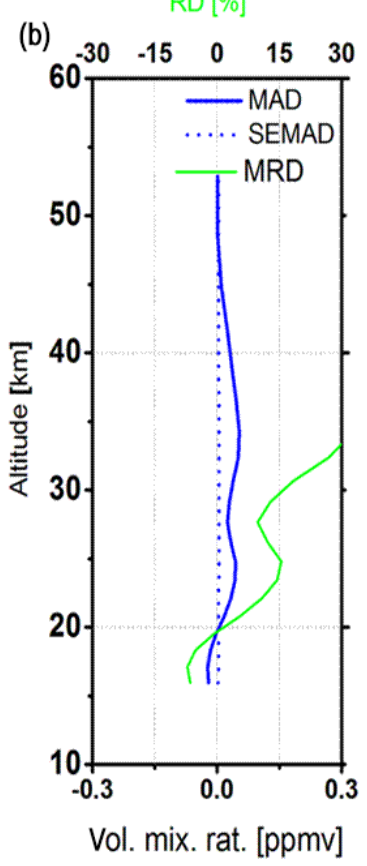

(c)

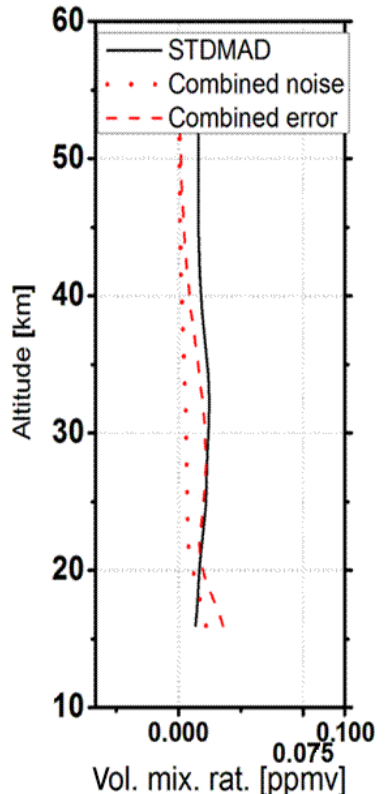

Figure 9. Comparison of $\mathrm{N}_{2} \mathrm{O}$ from MIPAS (V5R_N2O_224) and FTIR. Details as in Fig. 11.

(a)

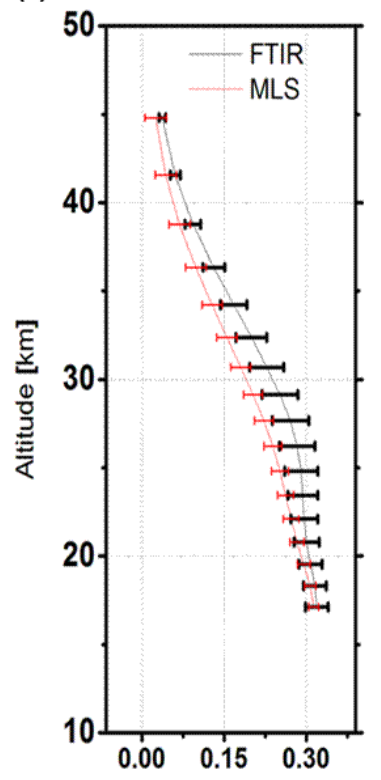

Vol. mix ratio [ppmv]

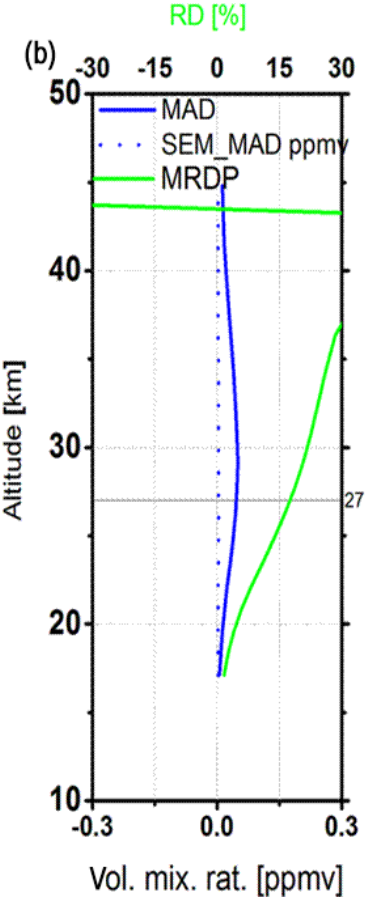

Figure 10. Comparison of $\mathrm{N}_{2} \mathrm{O}$ from MLS (V3.3) and FTIR. Details as in Fig. 11. 

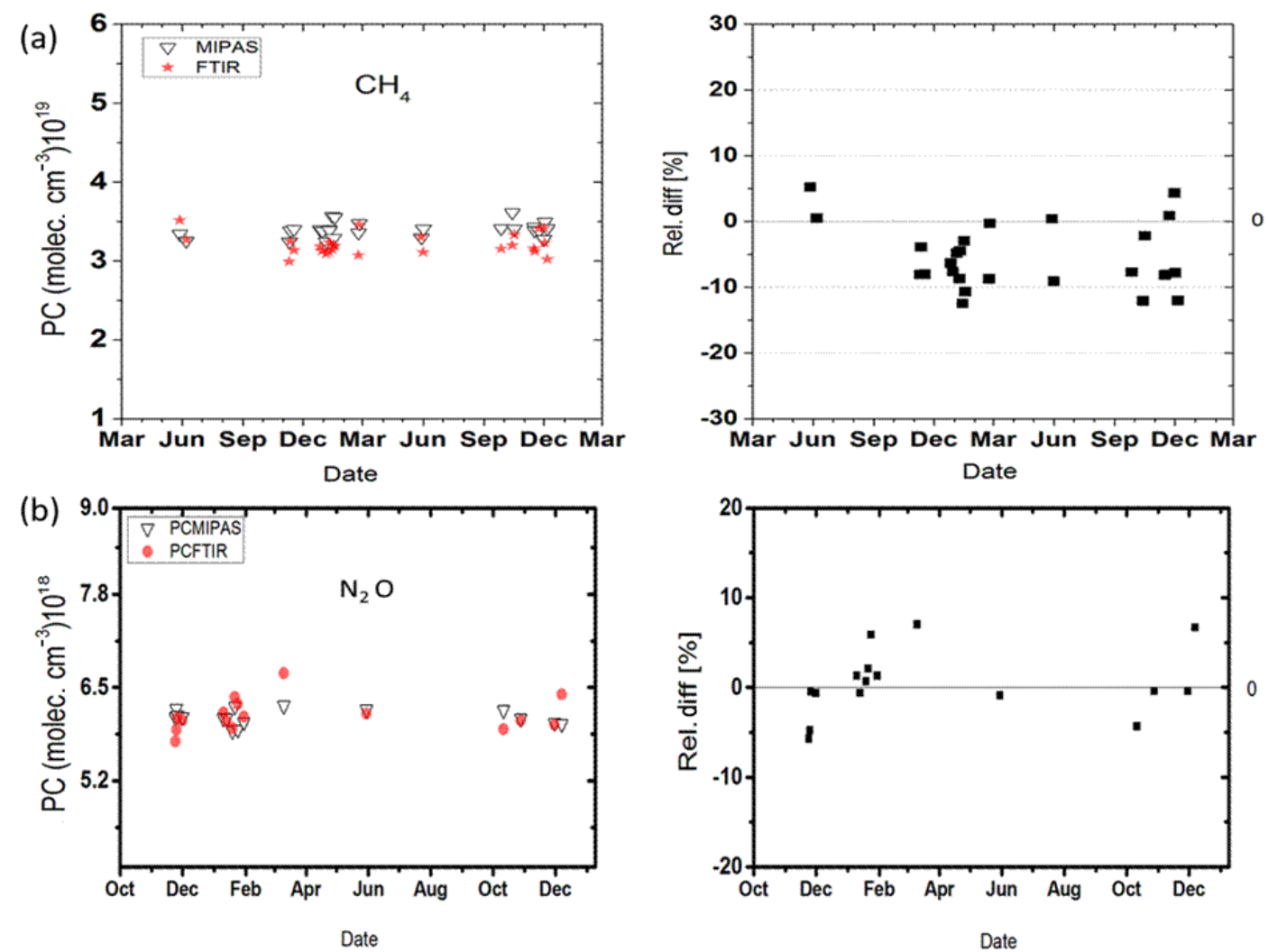

Figure 11. Time series of (a) $\mathrm{CH}_{4}$ and (b) $\mathrm{N}_{2} \mathrm{O}$ partial-column comparisons for the altitude range of 15-27 km. Right panels: ground-based FTIR (stars) and MIPAS (V5R_CH4_224 and V5R_N2O_224) (inverted triangles) partial columns. Left panels: relative differences between ground-based FTIR and MIPAS (V5R_CH4_224 and V5R_N2O_224) partial columns.

\subsection{Comparisons of partial columns}

For the partial-column (PC) comparisons of FTIR with MIPAS, it is vital to take into account the lower altitude limit of MIPAS, which is $15 \mathrm{~km}$ for both target gases. The groundbased FTIR sensitivity is used to determine the upper altitude limit, which is reasonable up to $\sim 27 \mathrm{~km}$ for $\mathrm{CH}_{4}$ and $\mathrm{N}_{2} \mathrm{O}$ in the tropical atmospheric condition. Therefore, the PC that we use in the comparison is limited to the altitude range of $15-27 \mathrm{~km}$. The DOFs within these partial columns' limit are about 1.0 and 1.2 for $\mathrm{CH}_{4}$ and $\mathrm{N}_{2} \mathrm{O}$, respectively.

Figure 11 shows the time series of the partial columns and relative differences of $\mathrm{CH}_{4}$ (a) and $\mathrm{N}_{2} \mathrm{O}$ (b). The partialcolumn comparison of $\mathrm{CH}_{4}$ between values of FTIR and MIPAS revealed a mean error of $-5.5 \%$, mean squares error of $7.4 \%$, and standard deviation from the mean error of $5 \%$. Similarly, $\mathrm{N}_{2} \mathrm{O}$ values between FTIR and MIPAS revealed a mean error of $0.5 \%$, mean square error of $3.7 \%$, and standard deviation from mean error of $3.8 \%$; in the latter case a significant positive bias is observed, and in $\mathrm{CH}_{4}$ negative bias was obtained.

\section{Summary and conclusions}

The vertical profiles and partial columns of $\mathrm{CH}_{4}$ and $\mathrm{N}_{2} \mathrm{O}$ over Addis Ababa, Ethiopia, were derived from ground-based FTIR. The mean partial column of $\mathrm{CH}_{4}$ and $\mathrm{N}_{2} \mathrm{O}$ within the sensitivity ranges of the instrument, which is from the surface to around $27 \mathrm{~km}$, is determined as $2.85 \times 10^{19}$ molecules $\mathrm{cm}^{-2} \pm 5.3 \%$ and $5.16 \times$ $10^{18}$ molecules $\mathrm{cm}^{-2} \pm 6.95 \%$, respectively. Furthermore, the overall contribution of both statistical and systematic errors, i.e., a total error of $\mathrm{CH}_{4}$ and $\mathrm{N}_{2} \mathrm{O}$ from ground-based FTIR, is $3.1 \%$ and $3 \%$, respectively.

From comparison of FTIR $\mathrm{CH}_{4}$ and MIPAS_CH4_224 products, a statistically significant maximum negative bias of $-4.8 \%$ at an altitude of $15 \mathrm{~km}$ that extends to $21 \mathrm{~km}$ and maximum positive bias of $4.6 \%$ at an altitude $27 \mathrm{~km}$ were obtained. The largest negative bias is found at altitudes between 11 and $19 \mathrm{~km}$, with a maximum difference of $-0.08 \mathrm{ppmv}$ $(-4.8 \%)$ at around $15 \mathrm{~km}$, and a positive bias of less than $0.14 \mathrm{ppmv}(9 \%)$ is found at altitudes between 21 and $27 \mathrm{~km}$, with a maximum value at around $27 \mathrm{~km}$ in the FTIR $\mathrm{CH}_{4}$ comparison with AIRS. On the other hand, from a comparison of $\mathrm{CH}_{4}$ from ground-based FTIR and MLS version 3.3, we obtained a significant positive average bias of $0.12 \mathrm{ppmv}$ 
(6.7\%) in the altitude range of $20-27 \mathrm{~km}$ and a negative bias of $-1.7 \%$ at $17 \mathrm{~km}$. In the case of FTIR $\mathrm{N}_{2} \mathrm{O}$ and MIPAS_N2O_224, a significant positive bias of less than $15 \%$ in the altitude range of $22-27 \mathrm{~km}$ with a maximum value at around $25 \mathrm{~km}$ and a negative bias of $-7 \%$ at $17 \mathrm{~km}$ has been obtained. A positive bias of less than $18.6 \%$ for altitudes below $27 \mathrm{~km}$ is noted for $\mathrm{N}_{2} \mathrm{O}$ between FTIR and MLS, and its bias below $22 \mathrm{~km}$ is less than $8 \%$, which can be explained in terms of the systematic error of FTIR $\mathrm{N}_{2} \mathrm{O}$.

In general, the retrieved $\mathrm{CH}_{4}$ and $\mathrm{N}_{2} \mathrm{O}$ VMR and column amounts from Addis Ababa, tropical site, exhibited very good agreement with all coincident satellite observations in the altitude ranges of $17-27 \mathrm{~km}$ with a positive mean relative difference within $20-27 \mathrm{~km}$ and negative below $20 \mathrm{~km}$. In addition, the bias obtained from the comparison and precision of the FTIR measurements is also comparable. The intercomparisons of $\mathrm{CH}_{4}$ and $\mathrm{N}_{2} \mathrm{O}$ VMR from ground-based FTIR with data from MIPAS, MLS, and AIRS sensors on board satellites reported in this work establish main features that characterize the FTIR instruments at Addis Ababa. The FTIR data can be used in further scientific studies as it represents a unique environment of tropical Africa, a region poorly investigated in the past. Furthermore, the results of this intercomparison for FTIR observations with the satellites can ensure that FTIR can now be used to validate satellite missions. Thus, for the FTIR data, it is anticipated that the use of the data in further scientific studies may provide some insight into the processes that govern chemical transport and chemistry in the atmosphere as well as sources of green gases in this part of the globe.

Data availability. The FTIR Data at Addis Ababa is available on request from the authors. All other data sets are publicly available at archives indicated in the paper.

Supplement. The supplement related to this article is available online at: https://doi.org/10.5194/amt-13-4079-2020-supplement.

Author contributions. Conceptualization was by TYB and GMT; investigation was by TYB, GMT, TB, FH, and GPS; data processing was done by TYB; the methodology was by TYB, GMT, TB, FH, and GPS; writing and reviewing was done by TYB, GMT, TB, $\mathrm{FH}$, and GPS.

Competing interests. The authors declare that they have no conflict of interest.

Acknowledgements. We are grateful to Goddard Space Flight Center and WACCM for providing temperature, pressure, and a priori profiles of all molecules. We greatly acknowledge the MIPAS science teams for providing data used in this study. Finally, the first au- thor would like to thank Mekelle and Addis Ababa universities for the sponsorship of $\mathrm{PhD}$ study during which this work is conducted.

Review statement. This paper was edited by Helen Worden and reviewed by two anonymous referees.

\section{References}

Barthlott, S., Schneider, M., Hase, F., Blumenstock, T., Kiel, M., Dubravica, D., García, O. E., Sepúlveda, E., Mengistu Tsidu, G., Takele Kenea, S., Grutter, M., Plaza-Medina, E. F., Stremme, W., Strong, K., Weaver, D., Palm, M., Warneke, T., Notholt, J., Mahieu, E., Servais, C., Jones, N., Griffith, D. W. T., Smale, D., and Robinson, J.: Tropospheric water vapour isotopologue data $\left(\mathrm{H}_{2}^{16} \mathrm{O}, \mathrm{H}_{2}^{18} \mathrm{O}\right.$, and $\left.\mathrm{HD}^{16} \mathrm{O}\right)$ as obtained from NDACC/FTIR solar absorption spectra, Earth Syst. Sci. Data, 9, 15-29, https://doi.org/10.5194/essd-9-15-2017, 2017.

Borsdorff, T., Hasekamp, O. P., Wassmann, A., and Landgraf, J.: Insights into Tikhonov regularization: application to trace gas column retrieval and the efficient calculation of total column averaging kernels, Atmos. Meas. Tech., 7, 523-535, https://doi.org/10.5194/amt-7-523-2014, 2014.

Boucher, O., Friedlingstein, P., Collins, B., and Shine, K. P.: The indirect global warming potential and global temperature change potential due to methane oxidation, Environ. Res. Lett., 4, 044007, https://doi.org/10.1088/1748-9326/4/4/044007, 2009.

Chahine, M., Pagano, T., Aumann, H., Atlas, R., Barnet, C., Chen, L., Divakarla, M., Fetzer, E., Goldberg, M., Gautier, C., Granger, S., Irion, F. W., Kakar, R., Kalnay, E., Lambrigtsen, B., Lee, S., Marshall, J. L., McMillan, W., McMillin, L., Olsen, E. T., Revercomb, H., Rosenkranz, P., Smith, W., Staelin, D., Strow, L., Susskind, J., Tobin, D., and Wolf, W.: The Atmospheric Infrared Sounder (AIRS): improving weather forecasting and providing new insights into climate, B. Am. Meteorol. Soc., 87, 891-894, https://doi.org/10.1175/BAMS-87-7-891, 2006.

Collins, W. J., Sitch, S., and Boucher, O.: How vegetation impacts affect climate metrics for ozone precursors, J. Geophys. Res., 115, D23308, https://doi.org/10.1029/2010JD014187, 2010.

Crevoisier, C., Nobileau, D., Armante, R., Crépeau, L., Machida, T., Sawa, Y., Matsueda, H., Schuck, T., Thonat, T., Pernin, J., Scott, N. A., and Chédin, A.: The 2007-2011 evolution of tropical methane in the mid-troposphere as seen from space by MetOp-A/IASI, Atmos. Chem. Phys., 13, 4279-4289, https://doi.org/10.5194/acp-13-4279-2013, 2013.

Frankenberg, C, Bergamaschi, P., Butz, A., Houweling, S., Meirink, J. F., Notholt, J., Petersen, A. K., Schrijver, H., Warneke, T., and Aben, I.: Tropical methane emissions: A revised view from SCIAMACHY onboard ENVISAT, Geophys. Res. Lett., 35, L15811, https://doi.org/10.1029/2008GL034300, 2008a.

Frankenberg, C., Warneke, T., Butz, A., Aben, I., Hase, F., Spietz, P., and Brown, L. R.: Pressure broadening in the $2 \mathrm{v}_{3}$ band of methane and its implication on atmospheric retrievals, Atmos. Chem. Phys., 8, 5061-5075, https://doi.org/10.5194/acp-8-50612008, 2008b.

Fueglistaler, S., Dessler, A. E., Dunkerton, T. J., Folkins, I., Fu, Q., and Mote, P. W.: Tropical tropopause layer, Rev. Geophys., 47, RG1004, https://doi.org/10.1029/2008RG000267, 2009. 
Garcia, R. R., Marsh, D. R., Kinnison, D. E., Boville, B. A., and Sassi, F.: Simulation of secular trends in the middle atmosphere, 1950-2003, J. Geophys. Res., 112, D09301, https://doi.org/10.1029/2006JD007485, 2007.

Hansen, C.: Analysis of discrete ill-posed problems by means of the L-curve, Soc. Indust. Appl. Math., 34, 561-580, 1992.

Hase, F., Hannigan, J. W., Coffey, M. T., Goldman, A., Höpfner, M., Jones, N. B., Rinsland, C. P., and Wood, S. W.: Intercomparison of retrieval codes used for the analysis of high-resolution, ground-based FTIR measurements, J. Quant. Spectrosc. Ra., 87, 25-52, 2004.

Holton, J. R.: Introduction to dynamic meteorology, forth edition, Department of Atmospheric Science University of Washington, Elsevier Academic Press, 2004.

Holton, J. R. and Gettelman, A.: Horizontal transport and the dehydration of the stratosphere, Geophys. Res. Lett., 28, 2799-2802, https://doi.org/10.1029/2001GL013148, 2001.

IPCC (Intergovernmental Panel on Climate Change): Third Assessment Report: Climate Change 2007: The Scientific Basis, Chapter 4, Cambridge University Press, UK, 2007.

Jacobson, M. Z.: Fundamentals of Atmospheric Modeling, second edition, Stanford University, Cambridge University press, 2005.

Laeng, A., Plieninger, J., von Clarmann, T., Grabowski, U., Stiller, G., Eckert, E., Glatthor, N., Haenel, F., Kellmann, S., Kiefer, M., Linden, A., Lossow, S., Deaver, L., Engel, A., Hervig, M., Levin, I., McHugh, M., Noël, S., Toon, G., and Walker, K.: Validation of MIPAS IMK/IAA methane profiles, Atmos. Meas. Tech., 8, 5251-5261, https://doi.org/10.5194/amt-8-5251-2015, 2015.

Lambert, A., Read, W. G., Livesey, N. J., Santee, M. L., Manney, G. L., Froidevaux, L., Wu, D. L., Schwartz, M. J., Pumphrey, H. C., Jimenez, C., Nedoluha, G. E., Cofield, R. E., Cuddy, D. T., Daffer, W. H., Drouin, B. J., Fuller, R. A., Jarnot, R. F., Knosp, B. W., Pickett, H. M., Perun, V. S., Snyder, W. V., Stek, P. C., Thurstans, R. P., Wagner, P. A., Waters, J. W., Jucks, K. W., Toon, G. C., Stachnik, R. A., Bernath, P. F., Boone, C. D., Walker, K. A., Urban, J., Murtagh, D., Elkins, J. W., and Atlas, E.: Validation of the Aura Microwave Limb Sounder middle atmosphere water vapor and nitrous oxide measurements, J. Geophys. Res.-Atmos., 112, D24S36, https://doi.org/10.1029/2007JD008724, 2007.

Livesey, N. J., Filipak, M. J., Froidevaux, L., Read, W. G., Lambert, A., Santee, M. L., Jiang, J. H., Pumphrey, H. C., Waters, J. W., Cofield, R. E., Cuddy, D. T., Daffer, W. H., Drouin, B. J., Fuller, R. A., Jarnot, R. F., Jiang, Y. B., Knosp, B. W., Li, Q. B., Perun, V. S., Schwartz, M. J., Snyder, W. V., Stek, P. C., Thurstans, R. P., Wagner, P. A., Avery, M., Browell, E. V., Cammas, J.P., Christensen, L. E., Diskin, G. S., Gao, R. S., Jost, H.J., Loewenstein, M., Lopez, J. D., Nedelec, P., Osterman, G. B., Sachse, G. W., and Webster, C. R.: Validation of Aura Microwave Limb Sounder $\mathrm{O}_{3}$ and $\mathrm{CO}$ observations in the upper troposphere and lower stratosphere, J. Geophys. Res., 113, D15S02, https://doi.org/10.1029/2007JD008805, 2008.

Livesey, N. J., Read, W. G., Froidevaux, L., Lambert, A., Gloria, L. Manney, H. C. P., Santee, M. L., Schwartz, M. J., Wang, S., Richard, E. Cofield, D. T. C., Fuller, R. A., Jarnot, R. F., Jiang, J. H., Knosp, B. W., Paul, C. Stek, P. A. W., and Wu, D. L.: Earth Observing System(EOS), Aura Microwave Limb Sounder (MLS), Version 3.3 and 3.4 Level 2 data quality and description document, Tech. Rep. JPL D-33509, Jet Propulsion Laboratory, California Institute of Technology, Pasadena, CA, USA, 2013.
Meier, A., Toon, G. C., Rinsland, C. P., Goldman, A., and Hase, F.: Spectroscopic Atlas of Atmospheric Microwindows in the Middle Infrared; 2nd revised edition; IRF Technical Report 048 ISSN 0284-1738; Swedish Institute of Space Physics Kiruna, 2004.

Meirink, J. F., Bergamaschi, P., and Krol, M. C.: Fourdimensional variational data assimilation for inverse modelling of atmospheric methane emissions: method and comparison with synthesis inversion, Atmos. Chem. Phys., 8, 6341-6353, https://doi.org/10.5194/acp-8-6341-2008, 2008.

Mengistu Tsidu, G.: High-Resolution Monthly Rainfall Database for Ethiopia: Homogenization, Reconstruction, and Gridding, J. Climate, 25, 8422-8443, https://doi.org/10.1175/JCLI-D-1200027.1, 2012.

Mengistu Tsidu, G., Blumenstock, T., and Hase, F.: Observations of precipitable water vapour over complex topography of Ethiopia from ground-based GPS, FTIR, radiosonde and ERA-Interim reanalysis, Atmos. Meas. Tech., 8, 3277-3295, https://doi.org/10.5194/amt-8-3277-2015, 2015.

Michelsen, H. A., Irion, F. W., Manney, G. L., Toon, G. C., and Gunson, M. R.: Features and trends in Atmospheric Trace Molecule Spectroscopy (ATMOS) version 3 stratospheric water vapor and methane measurements, J. Geophys. Res., 105, 22713-22724, 2000 .

Minschwaner, K. and Manney, G. L.: Derived methane in the stratosphere and lower mesosphere from Aura Microwave Limb Sounder measurements of nitrous oxide, water vapor, and carbon monoxide, J. Atmos. Chem., 71, 253-267, https://doi.org/10.1007/s10874-015-9299-z, 2014.

Payan, S., Camy-Peyret, C., Oelhaf, H., Wetzel, G., Maucher, G., Keim, C., Pirre, M., Huret, N., Engel, A., Volk, M. C., Kuellmann, H., Kuttippurath, J., Cortesi, U., Bianchini, G., Mencaraglia, F., Raspollini, P., Redaelli, G., Vigouroux, C., De Mazière, M., Mikuteit, S., Blumenstock, T., Velazco, V., Notholt, J., Mahieu, E., Duchatelet, P., Smale, D., Wood, S., Jones, N., Piccolo, C., Payne, V., Bracher, A., Glatthor, N., Stiller, G., Grunow, K., Jeseck, P., Te, Y., and Butz, A.: Validation of version-4.61 methane and nitrous oxide observed by MIPAS, Atmos. Chem. Phys., 9, 413-442, https://doi.org/10.5194/acp-9413-2009, 2009.

Petersen, A. K., Warneke, T., Frankenberg, C., Bergamaschi, P., Gerbig, C., Notholt, J., Buchwitz, M., Schneising, O., and Schrems, O.: First ground-based FTIR observations of methane in the inner tropics over several years, Atmos. Chem. Phys., 10, 7231-7239, https://doi.org/10.5194/acp-10-7231-2010, 2010.

Phillips, B. C.: A technique for the numerical solution of certain integral equations of the first kind, J. Ass. Comput. Mach., 9, 84-97, https://doi.org/10.1145/321105.321114, 1962.

Plieninger, J., von Clarmann, T., Stiller, G. P., Grabowski, U., Glatthor, N., Kellmann, S., Linden, A., Haenel, F., Kiefer, M., Höpfner, M., Laeng, A., and Lossow, S.: Methane and nitrous oxide retrievals from MIPAS-ENVISAT, Atmos. Meas. Tech., 8, 4657-4670, https://doi.org/10.5194/amt-8-4657-2015, 2015.

Plieninger, J., Laeng, A., Lossow, S., von Clarmann, T., Stiller, G. P., Kellmann, S., Linden, A., Kiefer, M., Walker, K. A., Noël, S., Hervig, M. E., McHugh, M., Lambert, A., Urban, J., Elkins, J. W., and Murtagh, D.: Validation of revised methane and nitrous oxide profiles from MIPAS-ENVISAT, Atmos. Meas. Tech., 9, 765-779, https://doi.org/10.5194/amt-9-765-2016, 2016. 
Rinsland, C. P., Boone, C., Nassar, R., Walker, K., Bernath, P., Mahieu, E., Zander, R., J. C. McConnell, J. C., and Chiou, L.: Trends of $\mathrm{HF}, \mathrm{HCl}, \mathrm{CCl}_{2} \mathrm{~F}_{2}, \mathrm{CCl}_{3} \mathrm{~F}, \mathrm{CHClF}_{2}$ (HCFC-22), and $\mathrm{SF}_{6}$ in the lower stratosphere from Atmospheric Chemistry Experiment (ACE) and Atmospheric Trace Molecule Spectroscopy (ATMOS) measurements near $30^{\circ} \mathrm{N}$ latitude, Geophys. Res. Lett., 32, L16S03, https://doi.org/10.1029/2005GL022415, 2005.

Rodgers, C. D.: Inverse Methods for Atmospheric Sounding: Theory and Practise, vol. 2 of Series on Atmospheric, Oceanic and Planetary Physics, World Scientific, 2000.

Rodgers, C. D.: Characterization and error analysis of profiles retrieved from remote sounding measurements, J. Geophys. Res. 95, 5587-5595, https://doi.org/10.1029/JD095iD05p05587, 1990.

Rodgers, C. D. and Connor, B. J.: Intercomparison of remote sounding instruments, J. Geophys. Res., 108, 4116, https://doi.org/10.1029/2002JD002299, 2003.

Ravishankara, A. R., Daniel, J. S., and Portmann, R. W.: Nitrous oxide $\left(\mathrm{N}_{2} \mathrm{O}\right)$ : The dominant ozone-depleting substance emitted in the 21st century, Science, 326, 123-125, https://doi.org/10.1126/science.1176985, 2009.

Rothman, L. S., Gordon, I. E., Barbe, A., Benner, D. C., Bernath, P. F., Birk, M., Boudon, V., Brown, L. R., Campargue, A., Champion, J. P., Chance, K., Coudert, L. H., Dana, V., Devi, V. M., Fally, S., Flaud, J. M., Gamache, R. R., Goldmanm, A., Jacquemart, D., Kleiner, I., Lacome, N., Lafferty, W., Mandin, J. Y., Massie, S. T., Mikhailenko, S. N., Miller, C. E., MoazzenAhmadi, N., Naumenko, O. V., Nikitin, A. V., Orphal, J., Perevalov, V. I., A. Perrin, A. P. C., Rinsland, C. P., Rotger, M., Šimečková, M., Smith, M. A. H., Sung, K., Tashkun, S. A., Tennyson, J., Toth, R. A., Vandaele, A. C., and Auwera, J. V.: The HITRAN 2008 molecular spectroscopic database, J. Quant. Spectrosc. Ra., 110, 533-572, 2009.

Rothmann L. S., Gordon, I. E., Babikov, Y., Barbe, A., Benner, D. C., Bernath, P. F., Birk, M., Bizzocchi, L., Boudon, V., Brown, L. R., Campargue, A., Chance, K., Coudert, L. H., Devi, V. M., Drouin, B. J., Fayt, A., Flaud, J. M., Gamache, R. R., Harrison, J., Hartmann, J. M., Hill, C., Hodges, J. T., Jacquemart, D., Jolly, A., Lamouroux, J., LeRoy, R. J., Li, G., Long, D., Mackie, C. J., Massie, S. T., Mikhailenko, S., Müller, H. S. P., Naumenko, O. V., Nikitin, A., Orphal, J., Perevalov, V. I., Perrin, A., Polovtseva, E. R., Richard, C., Smith, M. A. H., Starikova, E., Sung, K., Tashkun, S. A., Tennyson, J., Toon, G. C., Tyuterev V. G., and Wagner, G.: The HITRAN 2012 molecular spectroscopic database, J. Quant. Spectrosc. Ra., 130, 4-50, https://doi.org/10.1016/j.Jqsrt.2013.07.002, 2013.

Samuel, T. K.: Determination of Atmospheric Water Vapour Isotopic Composition using Multi-Platform Instruments and Models over Ethiopia: Implications for Water Cycle, PhD dissertation, Addis Ababa university, department of physics, 2014.

Schneider, M., González, Y., Dyroff, C., Christner, E., Wiegele, A., Barthlott, S., García, O. E., Sepúlveda, E., Hase, F., Andrey, J., Blumenstock, T., Guirado, C., Ramos, R., and Rodríguez, S.: Empirical validation and proof of added value of MUSICA's tropospheric $\delta \mathrm{D}$ remote sensing products, Atmos. Meas. Tech., 8, 483-503, https://doi.org/10.5194/amt-8-483-2015, 2015.

Schneider, M., Wiegele, A., Barthlott, S., González, Y., Christner, E., Dyroff, C., García, O. E., Hase, F., Blumenstock, T.,
Sepúlveda, E., Mengistu Tsidu, G., Takele Kenea, S., Rodríguez, S., and Andrey, J.: Accomplishments of the MUSICA project to provide accurate, long-term, global and high-resolution observations of tropospheric $\left\{\mathrm{H}_{2} \mathrm{O}, \delta \mathrm{D}\right\}$ pairs - a review, Atmos. Meas. Tech., 9, 2845-2875, https://doi.org/10.5194/amt-9-2845-2016, 2016.

Schoeberl, M. R., Douglass, A. R., Hilsenrath, E., Bhartia, P. K., Beer, R., Waters, J. W., Gunson, M. R., Froidevaux, L., Gille, J. C., Barnett, J. J., Levelt, P. F., and DeCola, P.: Overview of the EOS Aura mission, IEEE T. Geosci. Remote, 44, 1066-1074, 2006.

Senten, C., De Mazière, M., Dils, B., Hermans, C., Kruglanski, M., Neefs, E., Scolas, F., Vandaele, A. C., Vanhaelewyn, G., Vigouroux, C., Carleer, M., Coheur, P. F., Fally, S., Barret, B., Baray, J. L., Delmas, R., Leveau, J., Metzger, J. M., Mahieu, E., Boone, C., Walker, K. A., Bernath, P. F., and Strong, K.: Technical Note: New ground-based FTIR measurements at Ile de La Réunion: observations, error analysis, and comparisons with independent data, Atmos. Chem. Phys., 8, 3483-3508, https://doi.org/10.5194/acp-8-3483-2008, 2008.

Solomon, S.: Stratopheric Ozone depletion: A review of Concepts and History, Rev. Geophys., 37, 275-315, 1999.

Stiller, G. P., Kiefer, M., Eckert, E., von Clarmann, T., Kellmann, S., García-Comas, M., Funke, B., Leblanc, T., Fetzer, E., Froidevaux, L., Gomez, M., Hall, E., Hurst, D., Jordan, A., Kämpfer, N., Lambert, A., McDermid, I. S., McGee, T., Miloshevich, L., Nedoluha, G., Read, W., Schneider, M., Schwartz, M., Straub, C., Toon, G., Twigg, L. W., Walker, K., and Whiteman, D. N.: Validation of MIPAS IMK/IAA temperature, water vapor, and ozone profiles with MOHAVE-2009 campaign measurements, Atmos. Meas. Tech., 5, 289-320, https://doi.org/10.5194/amt-5289-2012, 2012.

Sussmann, R., Borsdorff, T., Rettinger, M., Camy-Peyret, C., Demoulin, P., Duchatelet, P., Mahieu, E., and Servais, C.: Technical Note: Harmonized retrieval of column-integrated atmospheric water vapor from the FTIR network - first examples for longterm records and station trends, Atmos. Chem. Phys., 9, 89878999, https://doi.org/10.5194/acp-9-8987-2009, 2009

Sussmann, R., Forster, F., Rettinger, M., and Jones, N.: Strategy for high-accuracy-and-precision retrieval of atmospheric methane from the mid-infrared FTIR network, Atmos. Meas. Tech., 4, 1943-1964, https://doi.org/10.5194/amt-4-1943-2011, 2011.

Sussmann, R., Forster, F., Rettinger, M., and Bousquet, P.: Renewed methane increase for five years (2007-2011) observed by solar FTIR spectrometry, Atmos. Chem. Phys., 12, 4885-4891, https://doi.org/10.5194/acp-12-4885-2012, 2012.

Takele Kenea, S., Mengistu Tsidu, G., Blumenstock, T., Hase, F., von Clarmann, T., and Stiller, G. P.: Retrieval and satellite intercomparison of $\mathrm{O} 3$ measurements from ground-based FTIR Spectrometer at Equatorial Station: Addis Ababa, Ethiopia, Atmos. Meas. Tech., 6, 495-509, https://doi.org/10.5194/amt-6495-2013, 2013.

Tikhonov, A.: On the regularization of ill-posed problems, Dokl. Acad. Nauk SSSR, 153, 49-52, 1963b.

Tilmes, S., Kinnison, D. E., Garcia, R. R., Müller, R., Sassi, F., Marsh, D. R., and Boville, B. A.: Evaluation of heterogeneous processes in the polar lower stratosphere in the Whole Atmosphere Community Climate Model, J. Geophys. Res., 112, D24301, https://doi.org/10.1029/2006JD008334, 2007. 
von Clarmann, T.: Validation of remotely sensed profiles of atmospheric state variables: strategies and terminology, Atmos. Chem. Phys., 6, 4311-4320, https://doi.org/10.5194/acp-6-4311-2006, 2006.

von Clarmann, T.: Smoothing error pitfalls, Atmos. Meas. Tech., 7, 3023-3034, https://doi.org/10.5194/amt-7-3023-2014, 2014.

Waters, J. W., Froidevaux, L., Harwood, R. S., Jarnot, R. F., Pickett, H. M., Read, W. G., Siegel, P. H., Cofield, R. E., Filipiak, M. J., Flower, D. A., Holden, J. R., Lau, G. K., Livesey, N. J., Manney, G. L., Pumphrey, H. C., Santee, M. L., Wu, D. L., Cuddy, D. T., Lay, R. R., Loo, M. S., Perun, V. S., Schwartz, M. J., Stek, P. C., Thurstans, R. P., Boyles, M. A., Chandra, K. M., Chavez, M. C., Chen, G.S., Chudasama, B. V., Dodge, R., Fuller, R. A., Girard, M. A., Jiang, J. H., Jiang, Y., Knosp, B. W., LaBelle, R. C., Lam, J. C., Lee, K. A., Miller, D., Oswald, J. E., Patel, N. C., Pukala, D. M., Quintero, O., Scaff, D. M., Snyder, W. V., Tope, M. C., Wagner, P. A., and Walch, M. J.: The Earth Observing System Microwave Limb Sounder (EOS MLS) on the Aura satellite, IEEE T. Geosci. Remote, 44, 1075-1092, https://doi.org/10.1109/tgrs.2006.873771, 2006.
WMO: Greenhouse Gas Bulletin, The State of Green house Gases in the Atmosphere Based on Global Observations through 2009, No. 6, 24 November 2010.

Xiong, X., Maddy, E. S., Barnet, C., Gambacorta, A., Patra, P. K., Sun, F., and Goldberg, M.: Retrieval of nitrous oxide from Atmospheric Infrared Sounder: Characterization and validation, J. Geophys. Res.-Atmos., 119, 9107-9122, https://doi.org/10.1002/2013JD021406, 2014.

Xiong, X. Z., Barnet, C., Maddy, E., Sweeney, C., Liu, X. P., Zhou, L. H., and Goldberg, M.: Characterization and validation of methane products from the Atmospheric Infrared Sounder (AIRS), J. Geophys. Res., 113, G00A01, https://doi.org/10.1029/2007jg000500, 2008. 